Alina Barczyk

https://orcid.org/0000-0002-6596-8915

Instytut Historii Sztuki

Uniwersytet Łódzki

Jakub Sito

https://orcid.org/0000-0002-2670-1513

Instytut Sztuki

Polska Akademia Nauk

https://doi.org/10.18778/2084-851X.09.04

\title{
Warszawa i Łowicz Dwie kolegiackie kaplice Chrystusa Ukrzyżowanego w XVIII stuleciu
}

Streszczenie. Dwie kaplice wzniesione przy kolegiatach w Warszawie i w Łowiczu, mieszczące słynące łaskami krucyfiksy, wykazują liczne analogie, do których należą: lokalizacja na przedłużeniu północnych naw, powiązania obu kapituł kolegiackich oraz szczególny status świątyń kojarzonych z najważniejszymi osobami w Rzeczypospolitej - królem (a także, w szerszym ujęciu, Sejmem i kręgiem dworskim) oraz prymasem, czyli interrexem. Mimo że powstanie architektury kaplic dzieliło blisko pół wieku, dostrzec można wzajemne zależności zastosowanych form. Wnętrza posiadają tym więcej analogii, że kaplicę warszawską przekształcono z inicjatywy Jana Klemensa Branickiego w na początku lat 60. XVIII wieku - gdy powstawało mauzoleum w Łowiczu. Zaprezentowania analiza, oparta na kwerendach archiwalnych i obserwacjach in situ, pozwoliła na doprecyzowanie dotychczasowych ustaleń, ukazanie procesu budowy oraz przekształceń omawianych obiektów, a także poświadczenie zależności artystycznych pomiędzy kaplicami.

Słowa kluczowe: XVIII wiek, Branicki Jan Klemens, Łowicz, Warszawa, nowożytna architektura sakralna, mecenat biskupi, sztuka baroku, cudowne wizerunki, mauzolea, sztuka sepulkralna 
K

rólewska Warszawa oraz prymasowski Łowicz należały do najważniejszych miast rezydencjonalnych Rzeczypospolitej w dobie nowożytnej ${ }^{1}$. W powyższych ośrodkach w XVIII stuleciu powstały niezwykle istotne kaplice przeznaczone na ekspozycję późnogotyckich krucyfiksów. Oba krzyże z figurami Ukrzyżowanego pierwotnie zawieszono w nawach, a konieczność stworzenia odrębnych przestrzeni na potrzeby kultu była wynikiem m.in. przekazów o cudach, których doświadczano za ich pośrednictwem². Szczególna ranga rzeźb zbiegła się z aktywnością fundatorską wybitnych mecenasów. W efekcie kaplice - stołeczna i łowicka - odznaczały się godnymi uwagi formami architektonicznymi oraz nowatorskimi programami artystycznymi. Obie zostały zbudowane na przedłużeniu północnych naw i pozostawały pod opieką kapituł, choć ich powstanie finansowane było ze środków przekazywanych przez możnych kolatorów. W przypadku Łowicza „fabryka” stanowiła realizację woli wyrażonej w testamencie prymasa Adama Ignacego Komorowskiego, który przeznaczył tę partię świątyni na swoje mauzoleum ${ }^{3}$. W Warszawie kolata przekazywana była kolejnym rodom - prawo patronatu uzyskali m.in. Szembekowie i Braniccy ${ }^{4}$. Przedstawiciele ostatniej z wymienionych familii nie zostali wprawdzie po śmierci złożeni w kaplicy, jednak prawdopodobnie rozważali plan pochówku serc.

Cechami łączącymi obie inwestycje były też powiązania obu kapituł kolegiackich oraz szczególny status obu świątyń kojarzonych z najważniejszymi osobami w Rzeczypospolitej - królem (a także, w szerszym ujęciu, Sejmem i kręgiem dworskim) oraz prymasem, czyli interrexem ${ }^{5}$. Powiązania polityczne i personalne silnie warunkowały podejmowane przedsięwzięcia artystyczne. Kwestią oczywistą wydaje się oddziaływanie Warszawy na oddalony o blisko $80 \mathrm{~km}$ Łowicz. Wspólne pozostawały jednak nie tylko inspiracje i aspiracje - przy obu kaplicach zatrudniano tych samych bądź wywodzących się z tego samego kręgu architektów ${ }^{6}$. Mimo iż zasadnicze struktury obu budowli dzieliło blisko pół wieku, dostrzec można wzajemne zależności zastosowanych form. Tezę tę potwierdzają zarówno analizy obiektów (brył, planów, wystroju), jak i studia nad zachowanymi materiałami rękopiśmiennymi. W niniejszym artykule chcielibyśmy zaprezentować najważniejsze ustalenia dotyczące dziejów budowy i przekształceń wyżej wymienionych obiektów.

\footnotetext{
1 Warszawa 1980, passim; GAJEWSKi 1986, s. 560; Czyż 2010, s. 9-12; Sito 2013, s. 9-11; WARDZYŃSKI/JAMSKi/KOWALSKI 2013, s. 159; WARDZYŃSKi 2015b, s. 429; BARCZYK 2019, s. 415, 424. 2 AAW, sygn. WG-2, s. 85-86; AGAD, A. Ros., sygn. XI 66, k. 519; KRÓliK 1990, s. 163-164; CZYŻ 2010, s. 114.

ADŁ, t. 1, s. 31, 174, 278; LibROWSKi 1977, s. 264; GAJEWSKi 1986, s. 561.

4 AAW, sygn. WG-2, s. 90; AGAD, A. Ros., sygn. XI 66, passim; KRÓLIK 1990, s. 163.

Kompetencje arcybiskupów gnieźnieńskich oraz rolę Łowicza w posłudze prymasowskiej przybliża m.in.: SWĘDROWSKI 2012, s. 345-346, 357.

6 Por.: AGAD, A. Ros., sygn. XIII 63, k. 1; AGAD, A. Ros., sygn. XI 66, k. 533; TAtarkiewiCz 1955, s. 10; BARTCZAKOWA 1970, s. 127; GAJEWSKi 1986, s. 571-573.
} 
$63 \mid \begin{gathered}\text { TECHNE } \\ \text { TEX N H } \\ \text { SERIA NOWA }\end{gathered}$

$* * *$

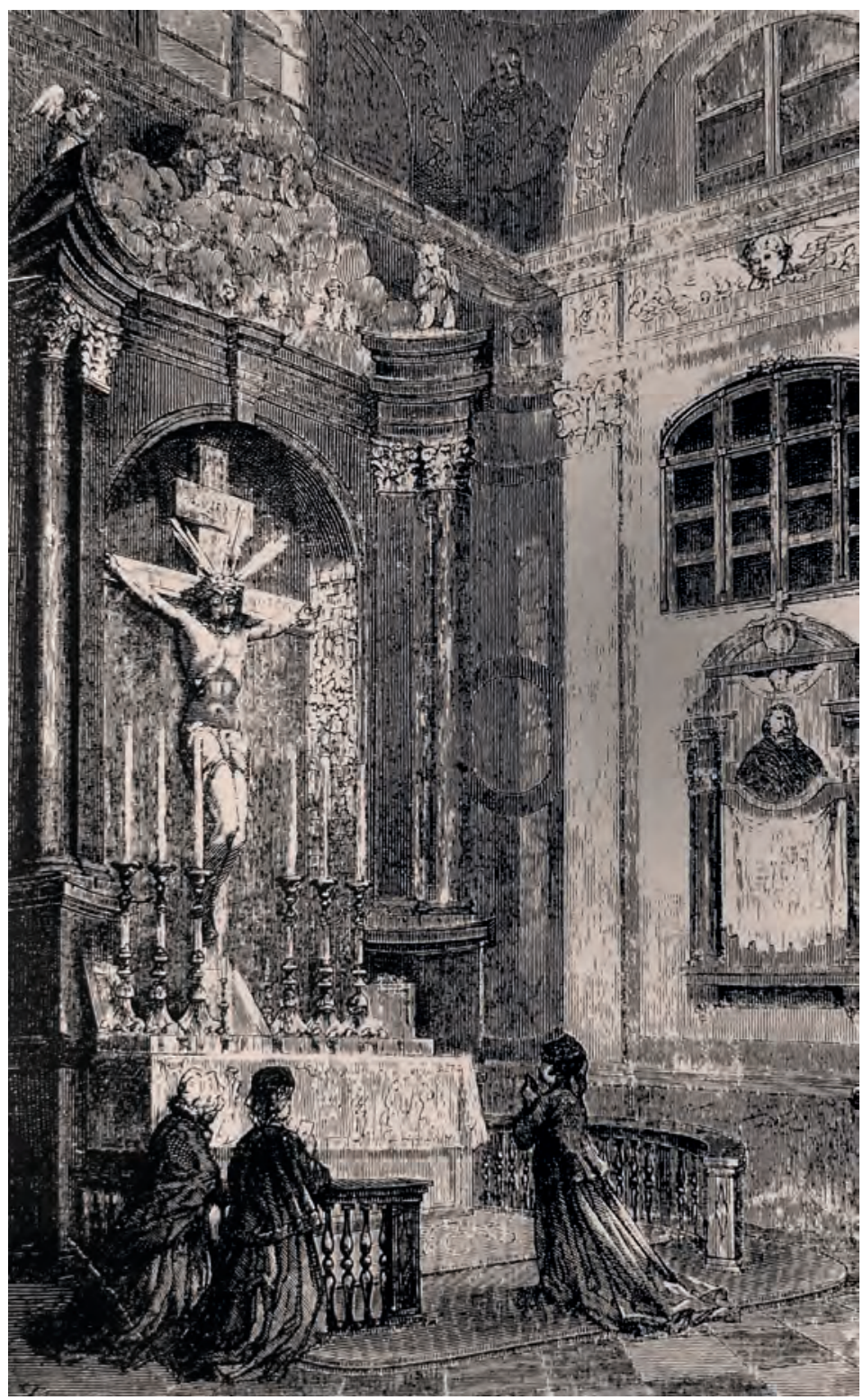

1. Wnętrze kaplicy Baryczkowskiej, ok. 1873-1900, za: Szypowscy 1999

Kaplicę przy obecnej katedrze św. Jana w Warszawie wzniesiono jako miejsce ekspozycji krucyfiksu (il. 1) - tak należy odczytywać jej pierwotną i wiodącą funkcję Figura Chrystusa została wykonana $\mathrm{z}$ drewna lipowego i przybrana peruką

7 AAW, sygn. WG-2, s. 85-90; Królik 1990, s. 131. 
z naturalnych włosów ${ }^{8}$, a dębowy krzyż obito blachą ${ }^{9}$. Jak głosi legenda, krucyfiks został sprowadzony przez burmistrza Starej Warszawy, Jerzego Baryczkę ${ }^{10}$, z Norymbergi, dzięki czemu miał uniknąć zniszczenia w czasie reformacji ${ }^{11}$. Wedle tradycji powyższe wydarzenie datowano na rok $1539^{12}$, jednak - jak zostało już ustalone przez dotychczasowych badaczy - krzyż przywieziono zapewne już w latach 20. XVI wieku ${ }^{13}$. Również informacja o pochodzeniu dzieła - do dziś pojawiająca się w części opracowań - wymaga doprecyzowania. Tadeusz Dobrzeniecki, a za nim Maria Kwiatkowska wskazywali na analogie do rzeźb wrocławskich, uznając, że prawdopodobnie $\mathrm{w}$ tym środowisku artystycznym wykonano warszawski krucyfiks ${ }^{14}$. Analiza faktów z biografii Jerzego Baryczki nie pozwala na jednoznaczne odrzucenie żadnej z powyższych wersji. Burmistrz utrzymywał bowiem kontakty handlowe m.in. z Norymbergą, Gdańskiem, Wilnem czy Poznaniem ${ }^{15}$. Potwierdzone źródłowo są także jego pobyty we Wrocławiu, gdzie gościł w 1520 roku (co było jednym $z$ argumentów historyków sztuki opowiadających się za śląskim pochodzeniem dzieła $)^{16}$. Baryczkowie należeli do grupy najznamienitszych rodów kupieckich $^{17}$. Dzięki handlowi zbożem i suknem stali się patrycjuszami o znaczących ambicjach politycznych i społecznych ${ }^{18}$. W XVII wieku uzyskali nobilitację, lecz poszczególni przedstawiciele tej familii już wcześniej obejmowali kolejne ważne funkcje i urzędy, z których przywołać można choćby stanowiska: starszego ławnika, wspomnianego wyżej burmistrza staromiejskiego ${ }^{19}$, owiesnego Władysława IV $^{20}$ czy sekretarza królewskiego ${ }^{21}$. Awans rodu wzmagał także aktywność fundatorską - jego

\footnotetext{
8 Po II wojnie światowej głowę Jezusa okryto peruką z końskiego ogona. Kolejnej zmiany dokonano w czasie ostatniej konserwacji (2020), przywracając pierwotny zamysł i wprawiając naturalne włosy ludzkie, zob. IDZIK 2020, s. 31.

9 IDZIK 2020, s. 26.

10 Postać Jerzego Baryczki przybliżają m.in.: BARUCH 1914, s. 33-43; DobRZENIECKI 1948, s. 234; SZYBKowSKi 2017, s. 296.

11 Przekaz o uratowaniu krzyża przed aktami ikonoklazmu został utrwalony m.in. w siedemnastowiecznych aktach Konsystorza Warszawskiego, zob. PABIś-GAGIS/WOZIŃSKi 2009, s. 15-16; IDZIK 2020, s. 25.

12 DobrZENIECKi 1948, s. 232; SobiesZCZAŃSKi 1967, s. 23; Warszawa 1980, s. 45.

13 Kwiatkowska 1978, s. 26; Lileyko 1989, s. 27; Jurkowlaniec 2008, s. 199. Na tablicy wmontowanej w katedrze, blisko portalu kaplicy, podana jest informacja: [krucyfiks] pochodzi z Norymbergi, sprowadził go do Warszawy w r. 1525 rajca warszawski Jerzy Baryczka.

14 Dobrzeniecki 1948, s. 236-238; KwiatKowska 1978, s. 26.

15 Warszawa 1980, s. 36; ZAHORSKi 2017, s. 30.

16 KwiatKowska 1978, s. 26.

17 Warszawa 1980, s. 36; CHUdobA 1959, s. 304, 308; ZAHOrsKi 2017, s. 30.

18 DobrZENIECKi 1948, s. 234; Warszawa 1980, s. 36, 59, 96.

19 BARUCH 1914, s. 33-35; LILEYKO 1989, s. 34; SZYBKOWSKi 2017, s. 296.

20 ANK, ZDP, sygn. 410, k. 1r.

21 BARUCH 1914, s. 64; FUKIER 1973, s. 30; Warszawa 1980, s. 96-97.
} 
przedstawiciele łożyli fundusze na „fabryki” klasztorne, dokonali także zapisu na krakowską bursę filozofów ${ }^{22}$. Sprowadzenie rzeźby Ukrzyżowanego i przekazanie jej do ówczesnej kolegiaty było więc jednym z gestów wpisujących się w działania mające potwierdzać pozycję Baryczków.

Pierwotnie krucyfiks wisiał w nawie, w pobliżu kruchty. Jednak w 1602 roku, po huraganie, który poczynił zniszczenia w kościele, przeniesiono go do kapitularza, a następnie umieszczono w ołtarzu Oczyszczenia Najświętszej Marii Panny ${ }^{23}$. Dopiero w XVIII stuleciu doczekał się własnej kaplicy (il. 2), zainicjowanej przez zapis testamentowy sekretarza królewskiego - Stanisława Kleinpoldta vel Kleinpolda Małopolskiego ${ }^{24}$. W pierwszej kolejności warto jednak w kilku słowach przybliżyć dalsze losy rzeźbiarskiego importu, który stał się niemal symbolem pobożności mieszkańców polskiej stolicy ${ }^{25}$. Podczas powstania warszawskiego krucyfiks został wyniesiony z płonącej katedry i umieszczony w kaplicy sióstr szarytek, która kilka dni po tym wydarzeniu została zbombardowana. Ocalałą figurę przetransportowano na ul. Freta, do dominikańskiego kościoła pw. św. Jacka, a następnie - już w 1945 roku, po wyzwoleniu miasta - do świątyni pokarmelickiej przy Krakowskim Przedmieściu ${ }^{26}$. W 1948 roku, po odbudowie dawnej kolegiaty, rzeźba powróciła w uroczystej procesji do kaplicy Baryczkowskiej (il. 3$)^{27}$.

Jak zostało wspomniane, inwestycję zapoczątkował Stanisław Kleinpoldt Małopolski - warszawski mieszczanin, który w 1676 roku uzyskał szlachectwo ${ }^{28}$ i pełnił m.in. funkcję metrykanta koronnego, sekretarza królewskiego i starosty bracławskiego $^{29}$. Na mocy testamentu spisanego w 1708 roku postanowił przeznaczyć 39000 złotych polskich na budowę kaplicy Pana Jezusa Ukrzyżowanego. Wbrew

22 BARUCH 1914, s. 96; Warszawa 1980, s. 96.

23 Zapewne już wtedy rzeźbę darzono wielką estymą, gdyż o godne wyeksponowanie i tym samym przeniesienie figury do ołtarza zabiegał zarówno biskup Jan Wężyk, jak i sam król, zob. AAW, sygn. WG-2, s. 88; SobIESZCZAŃSKi 1967, s. 22-23; KRÓLIK 1990, s. 163.

24 AAW, sygn. WG-2, s. 89; KUROWSKi 1841, s. 71-72; KRÓLIK 1990, s. 104. Intrygująco prezentują się zapisy z lat 30.-60. XVII wieku, dotyczące fundacji altarii. Wojciech Grzymalski, mansjonarz, został w 1662 roku odnotowany jako praepositus capellae Barickoviensis (AAW, LB, s. 284; SiEROCKA-PośPiech 2015, s. 161-162). Użyty termin „kaplica”, skonfrontowany z dziejami przebudów dzisiejszej katedry św. Jana, prowadzi do wniosków, że ołtarz z figurą Chrystusa został wydzielony. Oprawa miejsca tworzyłaby wówczas wrażenie przestrzennej odrębności.

25 Kaplica 1867, s. 1; DobrZENieCKi 1948, s. 236; SobIESZCZAŃSKi 1967, s. 22-23; IDZIK 2020, s. $28-29$.

26 Rzeźbę wydobyto z gruzów kościoła św. Jacka w trakcie poszukiwań trumny św. Andrzeja Boboli, zob. IDZIK 2020, s. 30.

27 Ibidem, s. 30-31.

28 Mossakowski 2012, s. 136.

29 Szlachcic używający spolszczonego nazwiska Małopolski był synem rajcy Starej Warszawy, królewskiego nadzorcy budowlanego - Erharda Kleinpolda (OsiECKA-SAMSONOwiCz 2016, s. 244, 246). Należała do niego m.in. parcela na Solcu (WĄTroBA 2019, s. 245-246). W 1671 roku zakupił on posesję przy ul. Długiej (nr hip. 556), na której wzniósł murowany, piętrowy dwór, 
TECHNE

T E X N H

SERIA NOWA

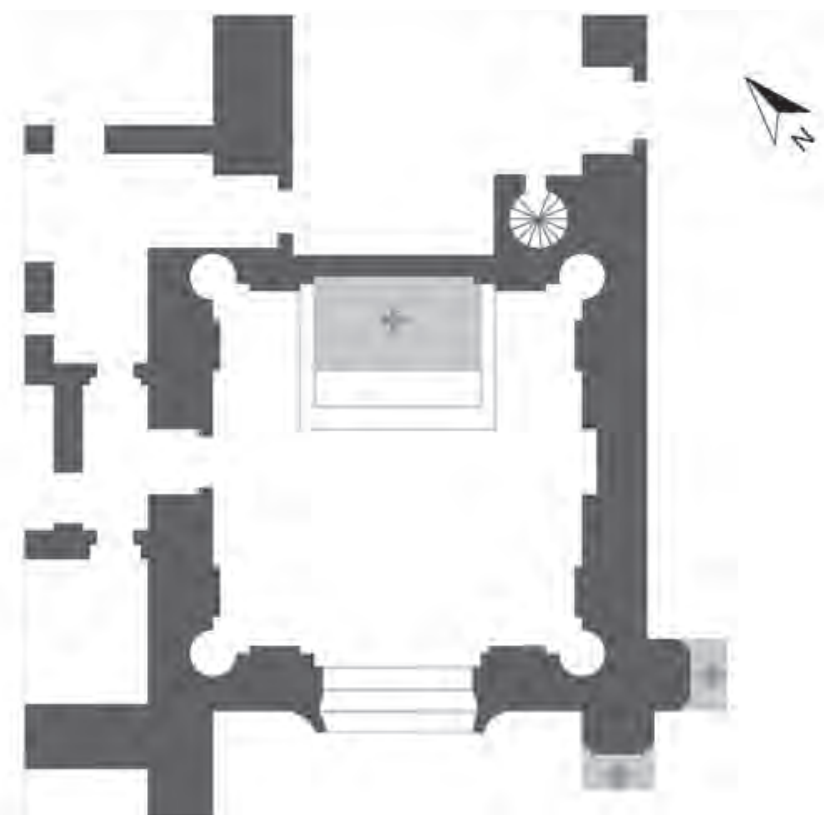

2. Kaplica Baryczkowska, rzut przyziemia - rekonstrukcja na podst. planu kolegiaty autorstwa Joachima Daniela Jaucha z 1735 roku, dokumentacji konserwatorskich i pomiarów współczesnych, oprac. autorka, 2020

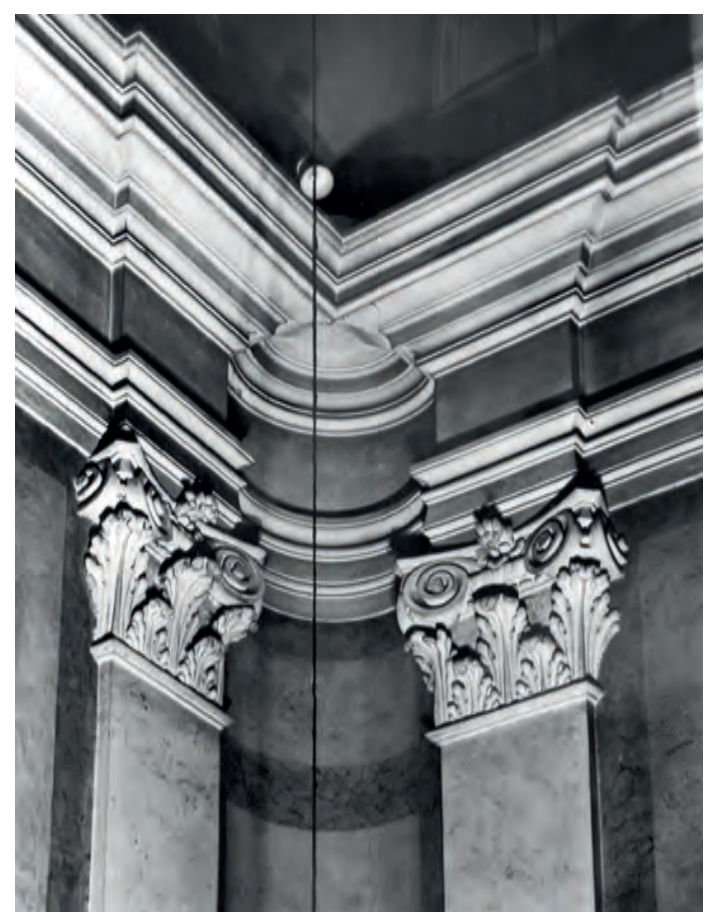

3. Kaplica Baryczkowska, narożnik, fot. Jerzy Langda, 1986, Instytut Sztuki PAN 
powszechnie przyjętym interpretacjom nie jest jednak prawdą, że data ta była tożsama $\mathrm{z}$ rozpoczęciem wznoszenia murów. Kaplica powstała bowiem dopiero w drugiej dekadzie XVIII wieku, na co wskazuje przede wszystkim relacja z wizytacji biskupa Antoniego Onufrego Okęckiego, stanowiąca jedno z nielicznych ocalałych źródeł rękopiśmiennych, które traktują o warszawskiej kolegiacie ${ }^{30}$. Fundamenty założono za czasów biskupa poznańskiego Michała Bartłomieja Tarły ${ }^{31}$ - zatem najwcześniej jesienią 1710 roku, gdyż Tarło objął to stanowisko kościelne 1 sierpnia ${ }^{32}$. Po śmierci metropolity we wrześniu 1715 roku $^{33}$ kapituła warszawska kontynuowała budowę. Ukoronowaniem inwestycji było ceremonialne przeniesienie krucyfiksu do nowo powstałej kaplicy, w której został wyeksponowany na ołtarzu z czarnego marmuru. Uroczystego aktu dokonał następca Tarły, biskup Krzysztof Antoni Szembek ${ }^{34}$, co pozwala zawęzić datację uroczystości na czas między wrześniem 1716 roku (kiedy objął diecezję poznańską) a lipcem 1720 roku (gdy został mianowany biskupem kujawskim) ${ }^{35}$. Akta klasztoru Karmelitów w Czernej - dysponenta łomów czarnego marmuru - wskazują z kolei na okres pomiędzy rokiem 1717 a 1720. Wedle tamtejszych zapisków jesienią 1716 roku trwały prace przy odkuwaniu ołtarza w wapieniu dębnickim $^{36}$. Montaż nastawy mógł zatem nastąpić prawdopodobnie w kolejnym roku. Przypuszczalnie równolegle prowadzono prace nad portalem wykonanym z tego samego materiału - byłoby to zgodne z powszechną praktyką łączenia zamówień dla jednego odbiorcy, które realizowano w kamieniołomach Dębnika ${ }^{37}$.

Kaplica Jezusa Ukrzyżowanego wybudowana została na planie kwadratu, na miejscu dawnego skarbca ${ }^{38}$. We wnętrzu zyskała półkoliście wydrążone naroża (il. 4) flankowane kompozytowymi pilastrami, na których wsparto belkowanie - obiegające całe pomieszczenie i wyłamane w narożach. Obiekt nakryto płaskim

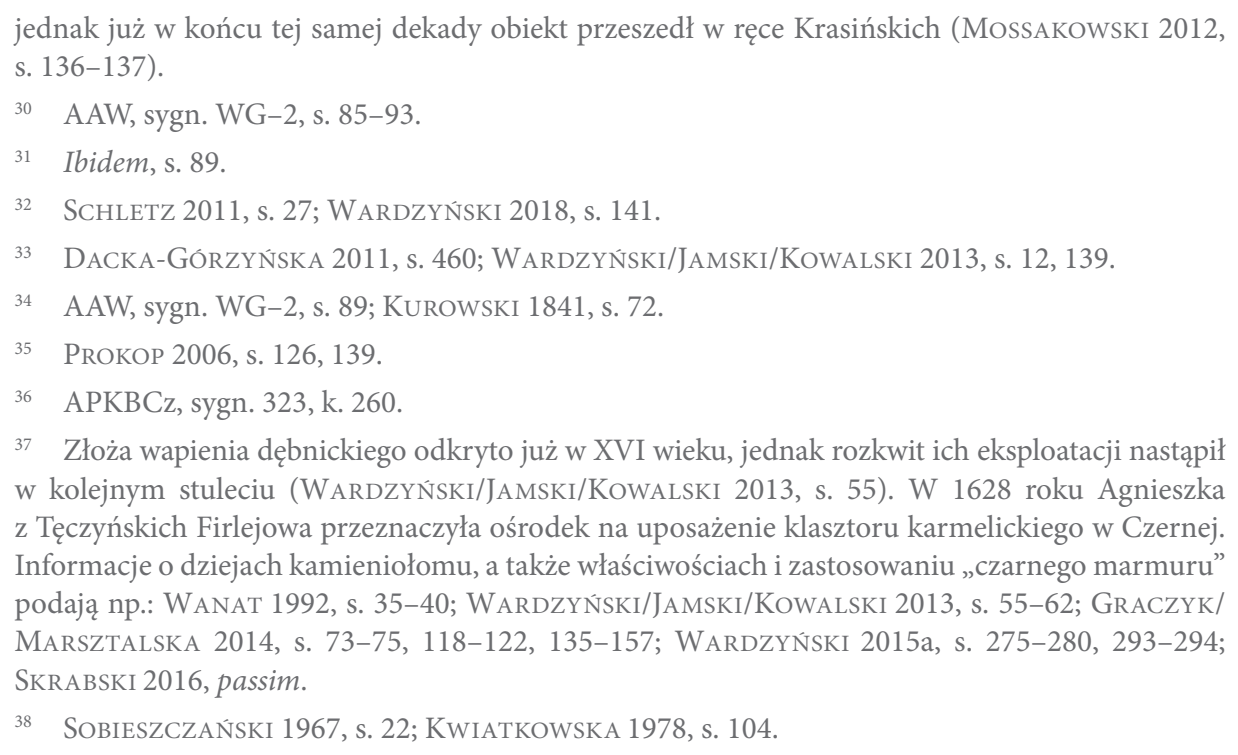
w kolejnym stuleciu (WARDZYŃSKi/JAMSKi/KowALSKI 2013, s. 55). W 1628 roku Agnieszka z Tęczyńskich Firlejowa przeznaczyła ośrodek na uposażenie klasztoru karmelickiego w Czernej. Informacje o dziejach kamieniołomu, a także właściwościach i zastosowaniu „czarnego marmuru” podają np.: WANAT 1992, s. 35-40; WARDZYŃSKI/JAMSKI/KOWALSKI 2013, s. 55-62; GRACZYK/ MARSZTALSKA 2014, s. 73-75, 118-122, 135-157; WARDZYŃSKI 2015a, s. 275-280, 293-294; SKRABSKI 2016, passim.

38 SobieszcZAŃSKi 1967, s. 22; KWIATKOWSKA 1978, s. 104. 
TECHNE

T E X N H

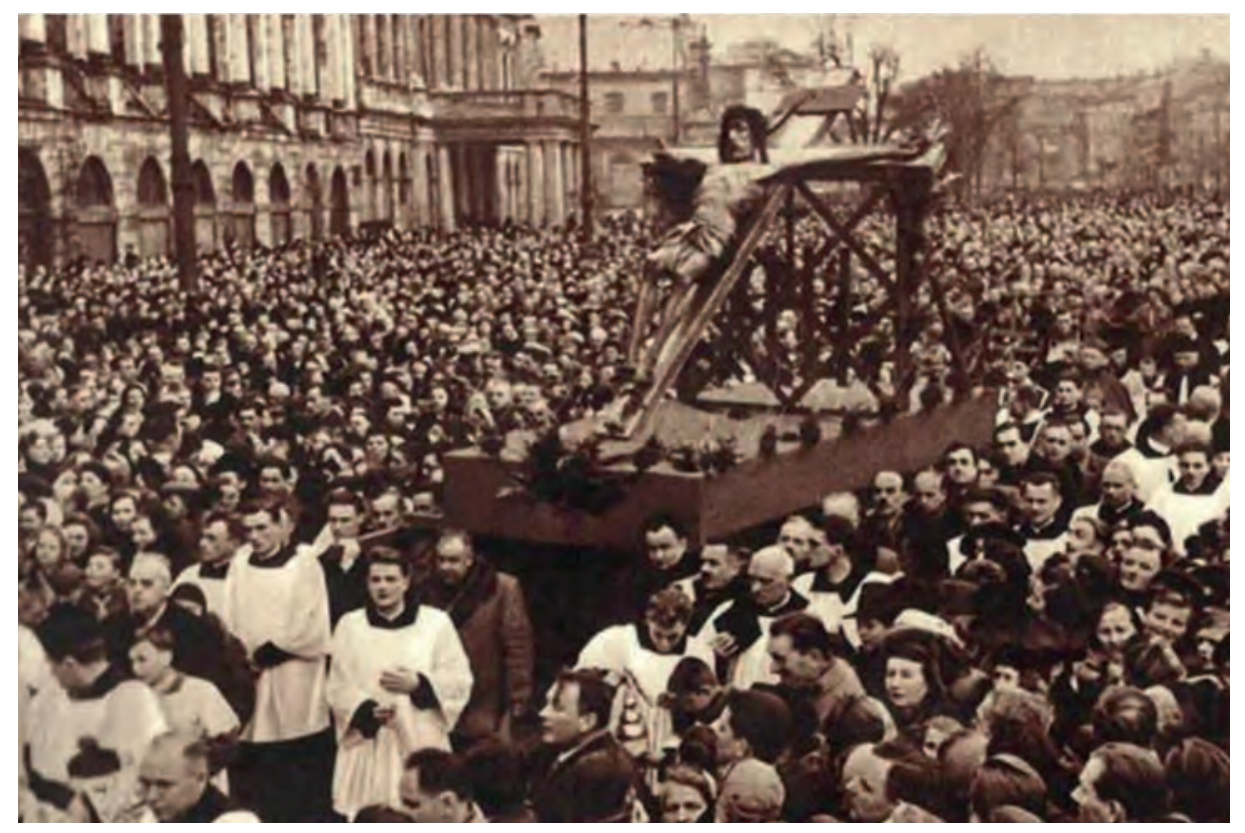

4. Wprowadzenie cudownego krucyfiksu do katedry św. Jana, 1948, za: IDzIK 2020

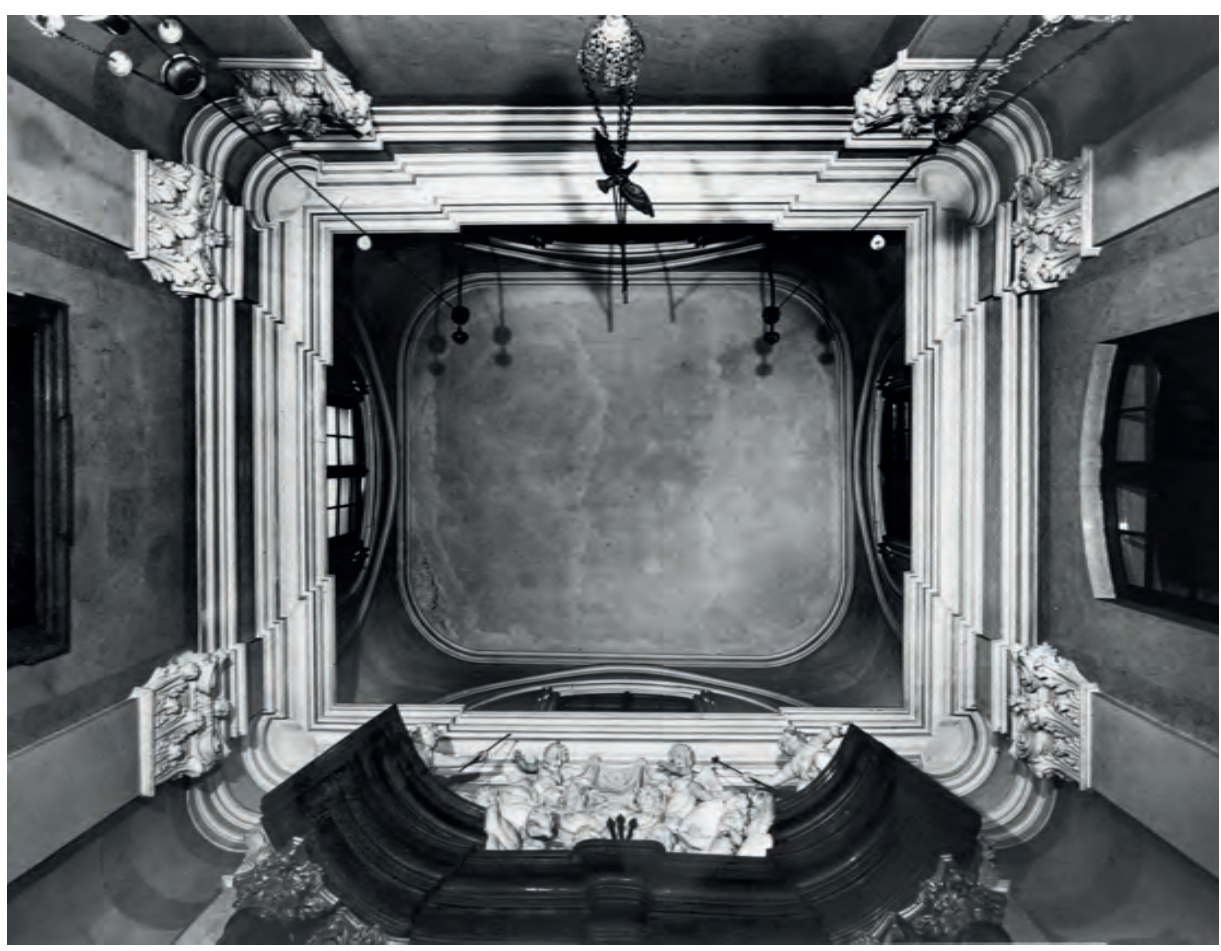

5. Kaplica Baryczkowska, sklepienie, fot. Jerzy Langda, 1986, Instytut Sztuki PAN 
- określanym przez to w źródłach mianem plafonu ${ }^{39}$ - sklepieniem nieckowym na pendentywach, w profilowanym obramieniu (il. 5). Okna na ścianach tarczowych zamknięto odcinkowo i ujęto uszakowymi obramieniami. Największym nowatorstwem, jak na 1716 rok, odznaczało się powtórzenie rozwiązania kompozycyjnego ołtarza w portalu wejściowym. Obie struktury zyskały dynamiczne, przestrzenne formy o krzywolinijnym planie i ukośnie ustawionych podporach - filarach w portalu i kolumnach w ołtarzu (il. 6-7). Na nich wsparto belkowanie na planie wycinka koła z przerwanymi przyczółkami na skrajach ${ }^{40}$. Odpowiednikiem półkoliście zamkniętej arkady wiodącej do wnętrza jest analogicznie zamknięte główne pole nastawy z Baryczkowską figurą. Ołtarz wieńczyła kompozycja ze stiuku z główkami i postaciami anielskimi wyłaniającymi się z obłoków i trzymającymi Arma Christi ${ }^{41}$. Co więcej, twórcom udało się uzyskać efekt scenograficzny: wklęsły narys portalu sprawiający wrażenie anektowania przestrzeni nawy przyczynił się do lepszej, kulisowej ekspozycji nastawy mieszczącej słynący łaskami krucyfiks. Kompozycja wprowadzona w obu dziełach posiada analogie w najbardziej innowacyjnej małej architekturze tego okresu. Z najbliższych punktów odniesienia przywołać warto przede wszystkim niezachowaną oprawę nagrobka książąt mazowieckich z lat 1723-1724 niemal bliźniaczą względem ołtarza Ukrzyżowania - de facto również zawierającą krzyż w partii centralnej ${ }^{43}$. Monument również znajdował się w kolegiacie św. Jana, co czyni powiązania tym bardziej oczywistymi. Dalszymi topograficznie, lecz równie ewidentnymi analogiami pozostają: nagrobek serc Branickich w Białymstoku (Stefana Mikołaja i jego matki - Katarzyny Aleksandry z Czarnieckich Branickich) ${ }^{44}$ oraz monument prymasa Michała Radziejowskiego w warszawskim kościele św. Krzyża (il. 8). Drugi z wymienionych obiektów wzniesiono w latach 1719-1722, a za projekt struktury architektonicznej odpowiedzialny był Carlo Antonio Bay ${ }^{45}$. Pierwotnymi źródłami inspiracji, które wpłynęły na wprowadzenie i popularyzację tego rodzaju kompozycji na ziemiach polskich, były oczywiście realizacje włoskie, a wśród nich ołtarz św. Marii Magdaleny (vel Noli me tangere) w rzymskim kościele Santi Domenico e Sisto, pochodzący z lat 1649-1650, zaprojektowany przez Gianlorenza

\footnotetext{
39 AGAD, A. Ros., sygn. XI 66, k. 529.

40 KWIATKOWSKA 1978, s. 104.

41 AAW, sygn. WG-2, s. 91; KWIATKOWSKA 1978, s. 104.

42 APKBCz, sygn. 324, k. 338, 344, 346.

43 Zależność obu dzieł była już sygnalizowana w literaturze, przykładowo w opracowaniu: KWIATKOWSKA 1978, s. 104-106.

44 NiECIECKi 1997, s. 5, 7-9.

45 Sito 2010a, s. 223-225; BANIA 2018, s. 139. W starszej literaturze zarówno wspomniane nagrobki (prymasa Radziejowskiego, książąt mazowieckich, serc Branickich), jak i portal i ołtarz kaplicy Baryczkowskiej przypisywano Kacprowi Bażance, zob. KWIATKOWsKA 1978, s. 104; NiECIECKI 1997, s. 9-11.
} 
TECHNE

T E X N H
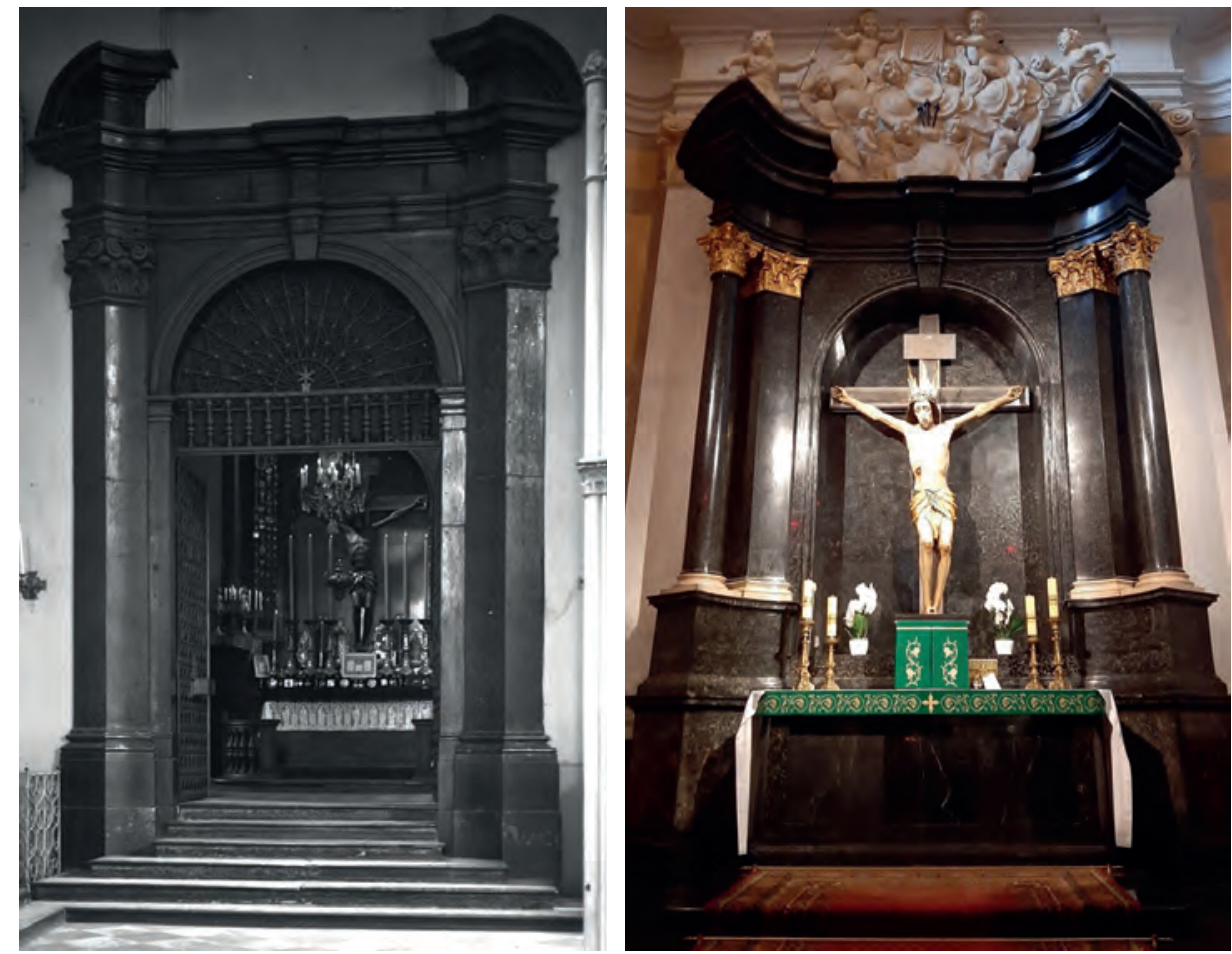

6. Kaplica Baryczkowska, od lewej: a) portal wejściowy, fot. Henryk Poddębski, 1925, Instytut Sztuki PAN; b) ołtarz, fot. autorka, 2020

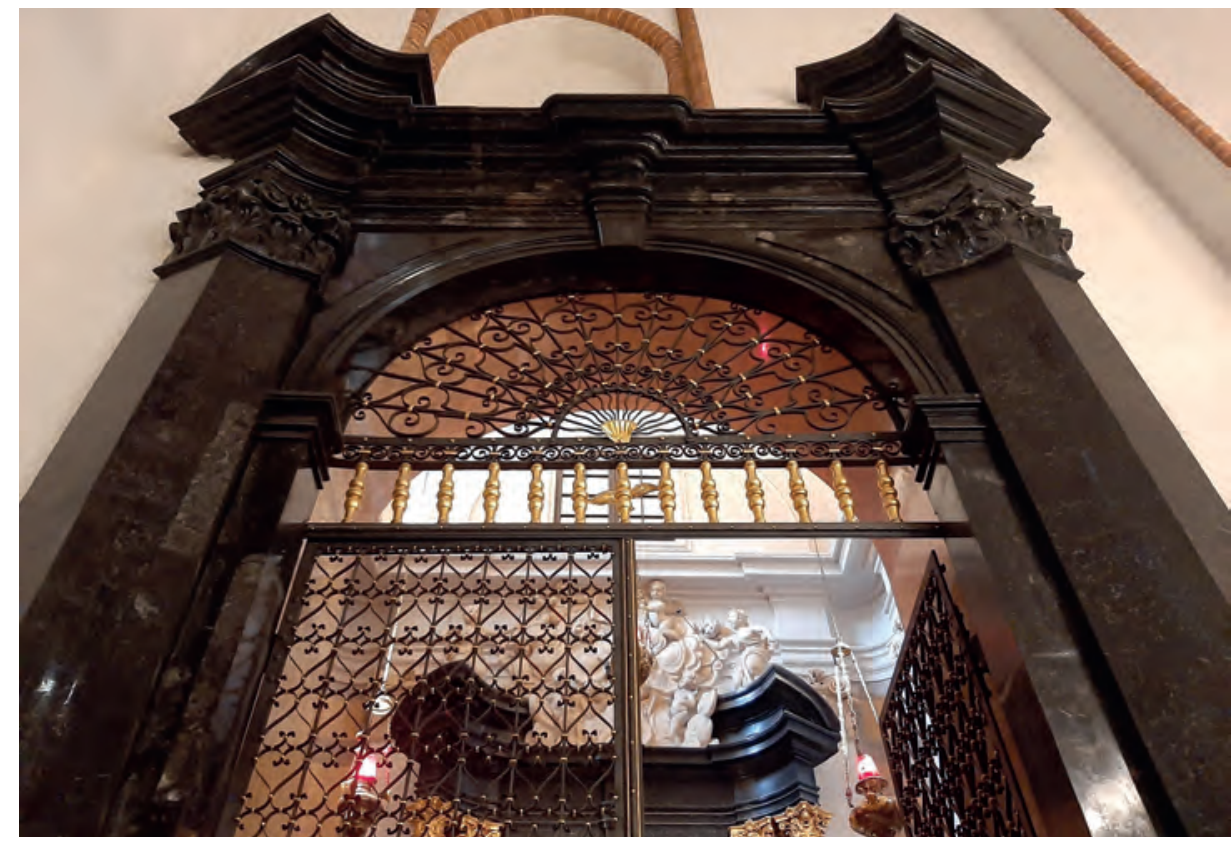

7. Kaplica Baryczkowska, portal wejściowy - detal, fot. autorka, 2020 

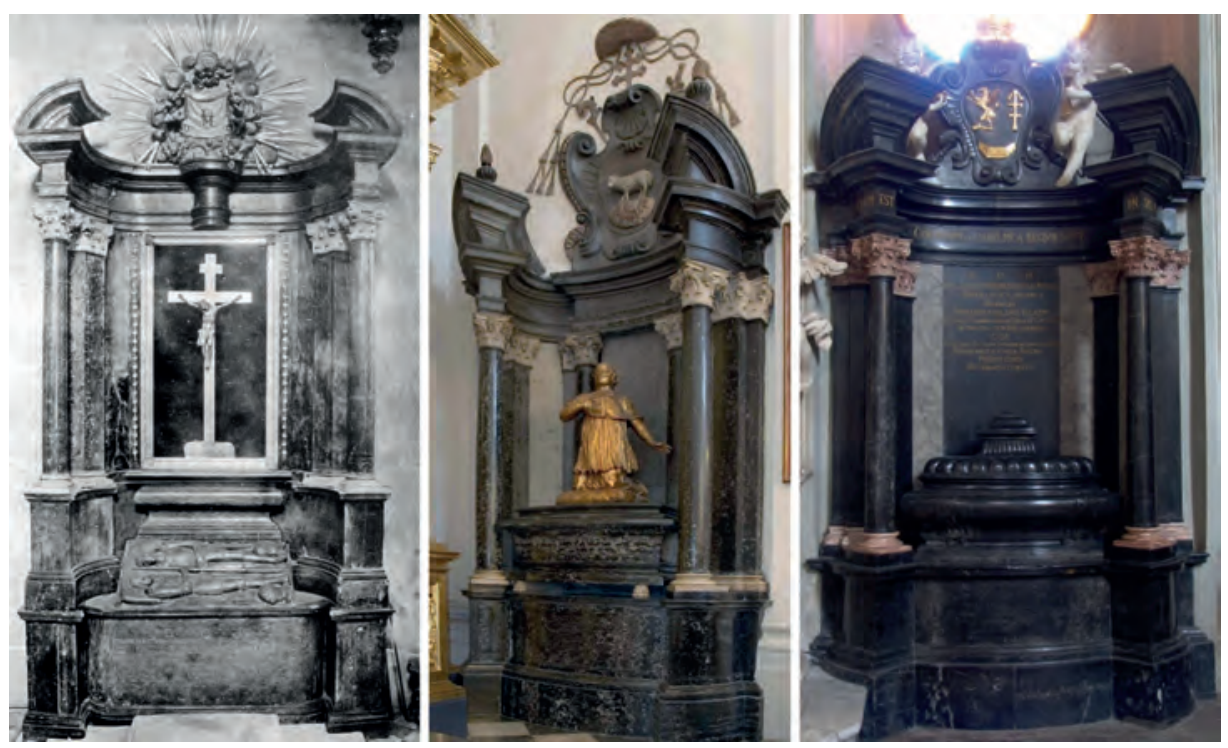

8. Od lewej: a) Warszawa, katedra św. Jana, oprawa nagrobka książąt mazowieckich, fot. przed 1939, Instytut Sztuki PAN; b) Warszawa, kościół św. Krzyża, nagrobek kardynała M. Radziejouskiego, fot. autor, 2018; c) Białystok, kościół farny, nagrobek serc Branickich, fot. autor, 2014

Berniniego $^{46}$, a zrealizowany przez Antonia Raggiego ${ }^{47}$. Spośród rycin przywołać warto tablicę z traktatu Andrei Pozza Perspectiva pictorum et architectorum (il. 9), obrazującą projekt pomnika cesarskiego na rzucie eliptycznym ${ }^{48}$. Genetyczne rozważania - sygnalizowane w literaturze, lecz zasługujące na odrębną, dogłębną analizę - prowadzą w pierwszej kolejności do poświadczenia związku kaplicy Baryczkowskiej z najbardziej aktualnymi tendencjami obecnymi w sztuce Rzeczypospolitej tego okresu.

Kaplica stała się miejscem pochówku kanclerza wielkiego koronnego Jana Szembeka, zmarłego w 1731 roku stryjecznego brata biskupa Krzysztofa Antoniego Szembeka. Tym bardziej prawdopodobna wydaje się teza, iż przedstawiciele tego rodu, z przyszłym prymasem Polski na czele, prowadzili „fabrykę” kaplicy i podejmowali decyzje dotyczące wprowadzonych we wnętrzu form i koncepcji, a także wyboru architekta. Bez wątpienia uwagę skierowano na twórcę związanego ze środowiskiem warszawskim. Prawdopodobnie zaangażowany został Carlo Antonio Bay ${ }^{49}$

46 KowalcZYK 1994, s. 235.

47 Ewidentnie rzymską genezę wskazywał już Mariusz Karpowicz (KARPOwiCz 1986, s. 168). Capella Alaleone (w świątyni Santi Domenico e Sisto) jako pierwowzór typu kompozycyjnego została ponownie przywołana m.in. w opracowaniach: NieCIECKI 1997, s. 11; Sito 2010a, s. 224.

48 Pozzo 1700, tabl. 1; BANia 2018, s. 139-140.

49 SITO 2016, s. 42. 
noszący tytuł „Architectus S.R.M." ${ }^{50}$ i pracujący przy innych obiektach wznoszonych dla Szembeków ${ }^{51}$. Z najważniejszych ustaleń dotyczących tego architekta - od lat budzącego dyskusje historyków sztuki różnie oceniających jego kompetencje i zakres działalności ${ }^{52}$ - warto przypomnieć, iż pochodził z Magliaso (w okolicach Lugano) i kształcił się w rzymskiej „szkole” Andrei Pozza ${ }^{53}$. Przed 1709 rokiem przyjechał do Rzeczypospolitej (zapewne za sprawą swego brata Antonia, który był kamieniarzem $\left.^{54}\right)$. Carlo Antonio Bay - potencjalny twórca warszawskiej kaplicy - rozwinął działalność w profesji budowniczego oraz architekta, projektując pałace, świątynie, a w szczególności liczne obiekty małej architektury o rzymskiej proweniencji ${ }^{55}$. Z twórcą powiązano Baryczkowski ołtarz i portal ${ }^{56}$. Oba dzieła wyróżniają się formami czerpanymi ze stolicy Italii, stanowią ponadto dość wczesne, jak na Warszawę, przykłady recepcji tego rodzaju rozwiązań. Argumentem przemawiającym za taką atrybucją są analogie do rozwiązań zastosowanych przez tego architekta w innych, potwierdzonych dziełach, takich jak założenie klasztorne w Siemiatyczach ${ }^{57}$. Zbieżność z rozwiązaniami wprowadzanymi przez Baya dostrzec można jednak nie tylko w portalu i ołtarzu, ale też w całej aranżacji kaplicy mieszczącej Baryczkowski krucyfiks. Szczególnie charakterystycznym rozwiązaniem stało się ukształtowanie drążonych narożników.

Kolejnymi kolatorami kaplicy stali się przedstawiciele rodu Branickich ${ }^{58}$. Zmiana ta nastąpiła najpóźniej w styczniu 1757 roku, co wynika z zachowanego listu Jana Klemensa Branickiego do burgrabiego Jana Lichomskiego, poświadczającego zamiar odnowienia obiektu poprzez montaż kryształowego okna ${ }^{59}$. Szeroko zakrojone prace przeprowadzono we wnętrzu w latach 1761-1762, co zostało

$50 \quad$ Kowalczy K 1994, s. 228; Bernatowicz 2016, s. 58.

51 Do oeuvre Baya należały: kościół Karmelitanek Bosych w Krakowie - zaprojektowany w roku 1716, zbudowany w latach 1719-1725 - oraz powstała w 1728 roku fara w podwarszawskich Babicach (KowALCZYK 1994, s. 229, 275). Obie świątynie fundowane były przez kanclerza koronnego Jana oraz Annę z Leszczyńskich Szembeków (SiTo 2016, s. 39).

52 Zagadnienie było poruszane m.in. w pracy: WARDZYŃSKI/JAMSKI/KOWALSKI 2013, s. 138, 157; ostatnio doczekało się analizy w ramach artykułu: BernatowiCz 2016, s. 57-60.

53 Nieciecki 1997, s. 48; Sito 2013, s. 89-90; Sito 2016, s. 37.

54 WARDZYŃSKi/JAMSKi/KOWALSKi 2013, s. 138.

55 WARDZYŃSKi 2015a, s. 46, 52; Sito 2013, s. 89-104.

56 Atrybucja przedstawiona w postaci hipotezy przez Mariusza Karpowicza (KARPOwiCz 1986, s. 168) mimo początkowego sceptycyzmu badaczy została podtrzymana i przyjęta w literaturze, zob. WARDZYŃSKi/JAMSKi/KOWALSKi 2013, s. 138; SiTO 2016, s. 42.

57 KARPOWICZ 1986, s. 166; ZdZIARSKA 1988, passim; BANIA 2018, s. 143-144.

58 AAW, sygn. WG-2, s. 90.

59 Hetman wielki koronny wspominał wówczas: dawno miałem intencja [sic!] dać okno kryształowe do kaplicy P. Jezusa (AGAD, A. Ros., sygn. 11, s. 208; OleńsKa 2011, s. 69). Powyższe zdanie Branickiego zdaje się wręcz sugerować, że zamiar przekształcenia (lub odnowienia) kaplicy musiał się zrodzić co najmniej kilka miesięcy wcześniej, zatem jeszcze w 1762 roku. 


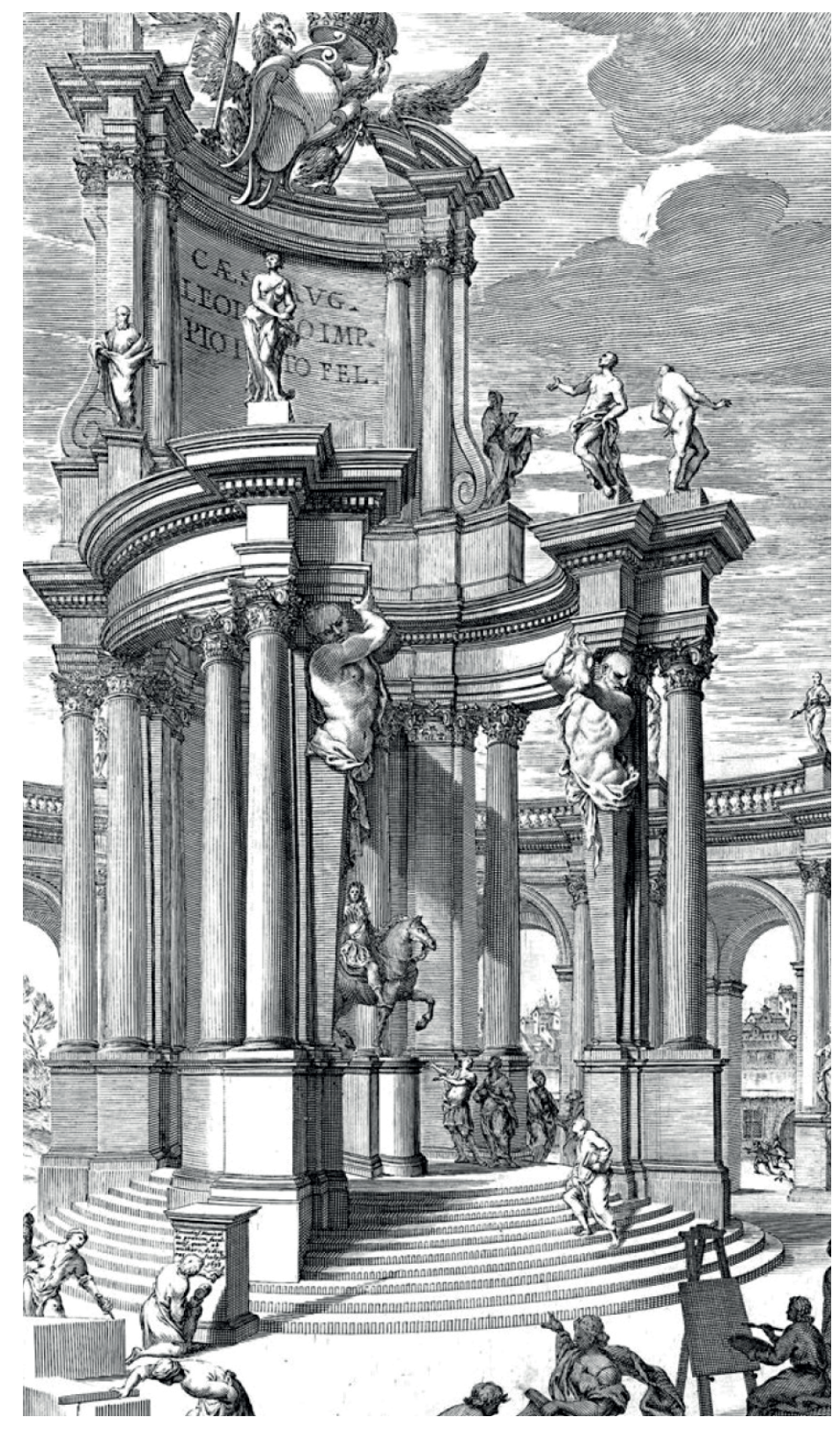

9. Andrea Pozzo, projekt pomnika cesarza Leopolda I, za: Pozzo 1700

udokumentowane w źródłach ${ }^{60}$ i upamiętnione inskrypcją widniejącą blisko przy wejściu: Pietate Joannis Clementis de Ruszcza et Branice Branicki, palatni cracoviensiducis exornatum A.D.1762. Dilexit decorem domus Dei. Analiza archiwaliów

${ }^{60}$ AAW, sygn. WG-2, s. 90; AGAD, A. Ros., sygn. XI 66, k. 516-557; AGAD, A. Ros., sygn. XIII 63, k. 1. 
jednoznacznie potwierdza, że architektami odpowiedzialnymi za inwestycję byli: Jakub Fontana ${ }^{61}$ - jeden $\mathrm{z}$ najważniejszych twórców warszawskich tego okresu ${ }^{62}$ - oraz Domenico Merlini ${ }^{63}$. W październiku 1761 roku postanowiono zastąpić dawne, kamienne kapitele ołtarza nowymi, wykonanymi z ołowiu i pokrytymi płatkowym złotem ${ }^{64}$. Zadania tego podjął się warszawski snycerz - Samuel Contessa ${ }^{65}$. $\mathrm{Na}$ decyzję związaną z wyborem materiału z pewnością wpływał fakt, że odlew ołowiany zapewniał ogromną precyzję i pozwalał na znacznie większą głębię reliefu. Ponadto Warszawa była w tym czasie ważnym centrum odlewnictwa cynowego i ołowianego, często wykorzystywanego także przy tworzeniu detali architektonicznych. Korespondencja kierowana przez Lichomskiego do Branickiego dostarcza godnych uwagi szczegółów dotyczących zakresu i (sekwencji) wykonywanych prac, dlatego warto przywołać najważniejsze z zawartych w niej informacji.

14 lutego burgrabia zapewniał, że wkrótce prześle gotowy abrys ołtarza Pana Jezusa ${ }^{66}$. W rzeczywistości projekt dotyczyć miał nie tyle nowej nastawy, co jedynie stiukowego zwieńczenia. Dwa miesiące później trwały ustalenia z księdzem podkustoszym jako gospodarzem kościoła konsultującym z biskupem i kapitułą szczegóły organizacyjne. Przedmiotem negocjacji był nie tylko termin rozpoczęcia prac (niż przejdzie do złocistej roboty to się czasu odwlecze i ciepła lepsze nastąią ${ }^{67}$ ), ale też tymczasowe przeniesienie słynącego łaskami krucyfiksu w inne miejsce ${ }^{68}$. Druga z wymienionych kwestii wzbudzała największe kontrowersje - obawiano się, że rzeźba może zostać przypadkowo uszkodzona, dlatego planowano ustawienie rusztowania po opuszczeniu przez nią kaplicy ${ }^{69}$. Ostatecznie kapituła podjęła decyzję o pozostawieniu figury w ołtarzu, jako że cudownych obrazów z miejsca na drugie miejsce przenosić się nie godzi ${ }^{70}$. Krucyfiks przykryto i obudowano deskami, wyno-

\footnotetext{
61 AGAD, A. Ros., sygn. XI 66, k. 533; KwiatKowsKa 1978, s. 106-107; OleŃsKa 2011, s. 69.

62 BartcZakowa 1970, passim; GajewsKi 2012, s. 80-81.

63 AGAD, A. Ros., sygn. XIII 63, k. 1; AGAD, A. Ros., sygn. XI 66, s. 533; WĄtrobA 2016, s. 314.

64 KWIATKOWSKa 1978, s. 106.

65 Contessa był zatrudniony m.in. przy przebudowie pałacu Czartoryskich przy Krakowskim Przedmieściu, gdzie - jako twórca wystroju części apartamentów - odnotowany został w latach 1758-1759, zob. SiTo 2010b, s. 10, 14, 16. Podstawowe informacje o artyście podaje: BernATOWICZ 1999, s. 3.

66 AGAD, A. Ros., sygn. XI 66, k. 516.

67 Wzmiankę o pogodzie podano w liście z 19 kwietnia 1762 roku, zob. AGAD, A. Ros., sygn. XI 66, k. 517.

68 Ibidem, k. 522.

695 maja 1762 roku w odpowiedzi na pytanie o datę rozpoczęcia prac burgrabia Lichomski pisał: dnia dzisiejszego Pana Jezusa do inszej kaplicy przeniosa, to jutro zaraz rusztowanie stawiać będziemy, zob. AGAD, A. Ros., sygn. XI 66, k. 519.

70 AGAD, A. Ros., sygn. XI 66, k. 522.
} 
sząc jedynie towarzyszące mu wota ${ }^{71}$. Od razu po tych zabiegach - 9 maja zmontowano rusztowanie ${ }^{72}$, a kilka dni później rozpoczęto $w$ oknie malarska robotę ${ }^{73}$. 8 czerwca do Warszawy dojechali malarze przysłani przez Branickiego z Białegostoku i już następnego dnia rozpoczęli dekorowanie kaplicy Pana Jezusa ${ }^{74}$. Artyści byli chwaleni przez Lichomskiego za szybką i sprawną pracę ${ }^{75}$, wyjątek stanowił pan Blesz, który swoim malowaniem bardzo powoli robi, ale dobrze $e^{76}$. Wspomnianym twórcą był z pewnością Jan Bogumił Plersch, jeden z najważniejszych malarzy związanych ze środowiskiem warszawskim, czynnych w późnych latach panowania Augusta III Sasa i aktywnych zwłaszcza w epoce stanisławowskiej ${ }^{77}$. W omawianej kaplicy spod jego pędzla wyszły: malowidło w technice al fresco przedstawiające Boga Ojca wśród obłoków oraz wyobrażenia czterech ewangelistów (tradycyjnie rozlokowanych w pendentywach $)^{78}$. Efektem prac zespołu malarzy było m.in. pozłocenie krat $^{79}$, kapiteli, fragmentów belkowania, a także snycerskiej oprawy wejścia do zakrystii - czyli drzwi adornowanych, które pan Fontanni [sic] zlecił Imci panu Merlemu ${ }^{80}\left[\right.$ sic!], aby odrysował ${ }^{81}$. W liście z 10 lipca Jan Lichomski proponował dodanie lamperii w partii cokołowej:

W tejże kaplicy Pana Jezusa od posadzki cokół, to jest na kształt lamperyji, jest malowany na murze czarno, tak wysoko, jak jest kamień nagrobka ś[w]. pamięci J.W. Pana Szembeka, kanclerza koronnego, ale by mnie się lepiej widziało, żeby ten cokół od stolarskiej roboty zrobiony mógł być, a po tym pod olej dobre pomalowanie dać, ponieważ na dole na murze trwało być nie może $e^{82}$.

\footnotetext{
71 Baryczkowski krucyfiks był otoczony znaczącą liczbą wotów, takich jak srebrny łańcuszek ofiarowany przez przedstawiciela rodu Potockich czy liczne wyobrażenia części ciała (oczu, serc, kończyn), przekazywanych w podziękowaniu za doznane uzdrowienia. W kaplicy znajdowały się też dary fundacji m.in. Szembeków i Mniszchów, zob. Kaplica 1867, s. 1; KRÓlIK 1990, s. 165.

72 AGAD, A. Ros., sygn. XI 66, k. 522. W liście z 24 maja Lichomski wskazywał, iż jest potrzebne 99 tynfów dla magistra cieśli za rusztowanie (ibidem, k. 524-525).

$73 \quad$ Ibidem, k. 522.

74 Ibidem, k. 526.

75 Ibidem, k. 526-527.

76 Cytat z listu datowanego na 26 czerwca, zob. AGAD, A. Ros., sygn. XI 66, k. 527.

77 Najważniejsze fakty na temat artysty, będącego synem nadwornego rzeźbiarza królewskiego Johanna Georga Plerscha, podają: Bernatowicz 2003, passim; Sito 2013, s. 304.

78 AAW, sygn. WG-2, s. 91; AGAD, A. Ros., sygn. XIII 63, k. 1; AGAD, A. Ros., sygn. XI 66, k. 529; KRÓliK 1990, s. 163.

79 Burgrabia relacjonował mecenasowi: kraty złociło się na mat, to jest jedna krata góra nad zakrystyją, druga krata przeciwko ni[ej], która krata da słuchu śpiewania księdza, ta też $i$ dla księdza organisty, bo za ta krata pozytyw stoi, który pozytyw służy najprzód do wielkiego ołtarza $i$ do kaplicy Pana Jezusa, co te kraty już sa pozłocone. Cytat za: AGAD, A. Ros., sygn. XI 66, k. 537.

80 Wspomnianymi twórcami byli oczywiście Jakub Fontana i Domenico Merlini.

81 AGAD, A. Ros., sygn. XI 66, k. 533-534.

82 Ibidem, k. 530.
} 
Artykulację kaplicy pokryto marmoryzacją już w pierwszej dekadzie sierpnia ${ }^{83}$, jednak zdobienia nie spełniły oczekiwań estetycznych i po już po upływie miesiąca dokonano w nich poprawek:

Pilastry w kaplicy Pana Jezusa jaśni[ej] przemalowane będą, ponieważ pan Antoni malarz gęsto żyłki dając, dlatego przyciemnił te pilastry. Dosyć ja mu mówił po kilkanaście razy, aby jaśni[ej] robił, teraz daje tę ekskuzę, że mu Imć. ksiądz kanonik Wincenty gęsto żyłki dawać kazał ${ }^{84}$.

Prace prowadzono też przy portalu wejściowym, stanowiącym „wizytówkę" kaplicy. Malarzom polecono gruntować i potem biało jak marmur zrobić stiukowe postacie aniołów, główki puttów i obłoki ${ }^{85}$. Jasna barwa kompozycji miała silnie kontrastować z czernią marmuru ${ }^{86}$. Równolegle wykonywano nowe wyposażenie wnętrza, choćby w postaci dębowych ławek ${ }^{87}$.

Najciekawszym zabiegiem, jaki przeprowadzono w trakcie rokokowej modernizacji, było obicie ścian czerwoną tkaniną. Materiał został wprawiony w snycerskie, złocone na połysk (na glanc) ramy wykonane według tego [przysłanego] modelu ${ }^{88}$. Listwy określono w źródłach mianem krzywych, co potwierdza, iż zostały zaokrąglone i wyprofilowane zgodnie $\mathrm{z}$ rokokową modą. Tempo prac nad ramami zależne było m.in. od dostaw złota, którego odbiór Lichomski odnotował w listach, prosząc o kolejne przesyłki - zwłaszcza że kapituła kolegiacka zabiegała, aby obicie w kaplicy Pana Jezusa mogło być jak najprędzej ${ }^{89}$. Równolegle z pracami snycerskimi przygotowywano samą tkaninę. Przed 10 lipca tapicer dokonał pomiarów wnętrza, szacując, jaka ilość materiału jest potrzebna na okrycie płaszczyzn pomiędzy pilastrami. Po blisko dwóch miesiącach, 13 września Jan Klemens Branicki został zapewniony, że obicie jest już gotowe i gdy tylko listwy zostaną ukończone, nastąpi finalny montaż. Do uszycia ściennej dekoracji wykorzystano cztery gatunki tkanin: dwie odmiany płótna (251 łokci zwykłego oraz 204 łokcie matowanego); 6 łutów karmazynowego jedwabiu i wreszcie około 277 łokci adamaszku ${ }^{90}$.

\footnotetext{
83 Ibidem, k. 537, 540.

$84 \quad$ Ibidem, k. 553.

85 Ibidem, k. 553. Źródła jednoznacznie potwierdzają, że informacje dotyczą grupy stiukowej nade drzwiami [...] do kaplicy Pana Jezusa (ibidem, k. 543), czyli nad krata (ibidem, k. 540). Można przypuszczać, że niezachowana kompozycja korespondowała formalnie ze zwieńczeniem ołtarza Ukrzyżowania.

86 Ibidem, k. 540.

87 Ibidem, k. 557. 25 sierpnia 1762 roku projekt ławek został przesłany Branickiemu (ibidem, k. 549).

88 Ibidem, k. 546-547.

89 Ibidem, k. 553.

$90 \quad$ Ibidem, k. 557.
} 
Trudności z precyzyjnym wyobrażeniem sobie efektu, jaki wywołał zabieg obicia ścian czerwoną, szlachetną tkaniną, wynikają z braku zachowanych przykładów tego rodzaju wystroju przestrzeni sakralnych. $\mathrm{Z}$ analogii czysto formalnych wspomnieć można jedynie wnętrza świeckie z tej samej dekady, a spośród exemplów bliskich geograficznie - Salon Czerwony w pałacu Ogińskich-Radziwiłłów w Nieborowie, w którym panele ścienne z materiałem (zarówno szerokie, jak i wąskie) zostały obramowane biało-złotymi listwami z dekoracją snycerską ${ }^{91}$. Należy jednak zaznaczyć, że sama tkanina była w nieborowskiej rezydencji wymieniana na nową już w 1898 roku $^{92}$.

Subtelny rokokowy charakter kaplicy Baryczkowskiej został zniweczony już w 1873 roku. Przeprowadzono wówczas „restaurację" w duchu neorenesansu - położono m.in. nową posadzkę, przekształcono kraty, a ściany, odarte już z karmazynowych obić, pokryto marmoryzacją. Projekt powyższych przekształceń opracował Bolesław Podczaszyński ${ }^{33}$.

Po II wojnie światowej kaplica Jezusa Ukrzyżowanego była najlepiej zachowanym fragmentem kościoła św. Jana. Na fotografiach z lat 1945-1946 widoczna jest m.in. ściana oddzielająca tę partię świątyni od nawy bocznej, zawierająca w sobie niemal pozbawiony zniszczeń portal wejściowy (il. 10). Silnych uszkodzeń kaplica doznała dopiero w 1947 roku wskutek zawalenia się ruin. W trakcie odbudowy, która nastąpiła w latach 1958-1960, dość wiernie zrekonstruowano dyspozycję przestrzenną wnętrza, łącznie z artykulacją ścian i sklepieniem. W większości można też dziś podziwiać wiernie zrekonstruowane wyposażenie. Największą stratą pozostaje brak tkanin z czasów Branickiego, które nadawały przestrzeni unikatowy charakter.

\footnotetext{
1 JaroszewsKi 1992, s. 118-119.

92 Wówczas Franciszek Wojciechowski, tapicer warszawski, naprężył nowym materiałem Salon Czerwony, zob. Nieborów 1970, s. 22.

93 Architekt pochodzenia wileńskiego, zdobył wykształcenie w Paryżu, pełnił funkcję wykładowcy akademickiego i budowniczego związanego przede wszystkim z ośrodkiem warszawskim. Do bardziej znanych realizacji Podczaszyńskiego, stanowiących modyfikacje wcześniejszych obiektów, należały przekształcenia założenia ogrodowego w Wilanowie, przebudowa Pałacu Kazimierzowskiego, rezydencji w Sieniawie i Werkach (k. Wilna), a także stworzenie dekoracji okolicznościowej w Pałacu Namiestnikowskim z okazji przyjazdu cara Aleksandra II, zob. FryCz 1975, s. 126; STEFAŃSKi 2005, s. 89-90, 120.
} 


\section{TECHNE \\ T E X N H \\ SERIA NOWA

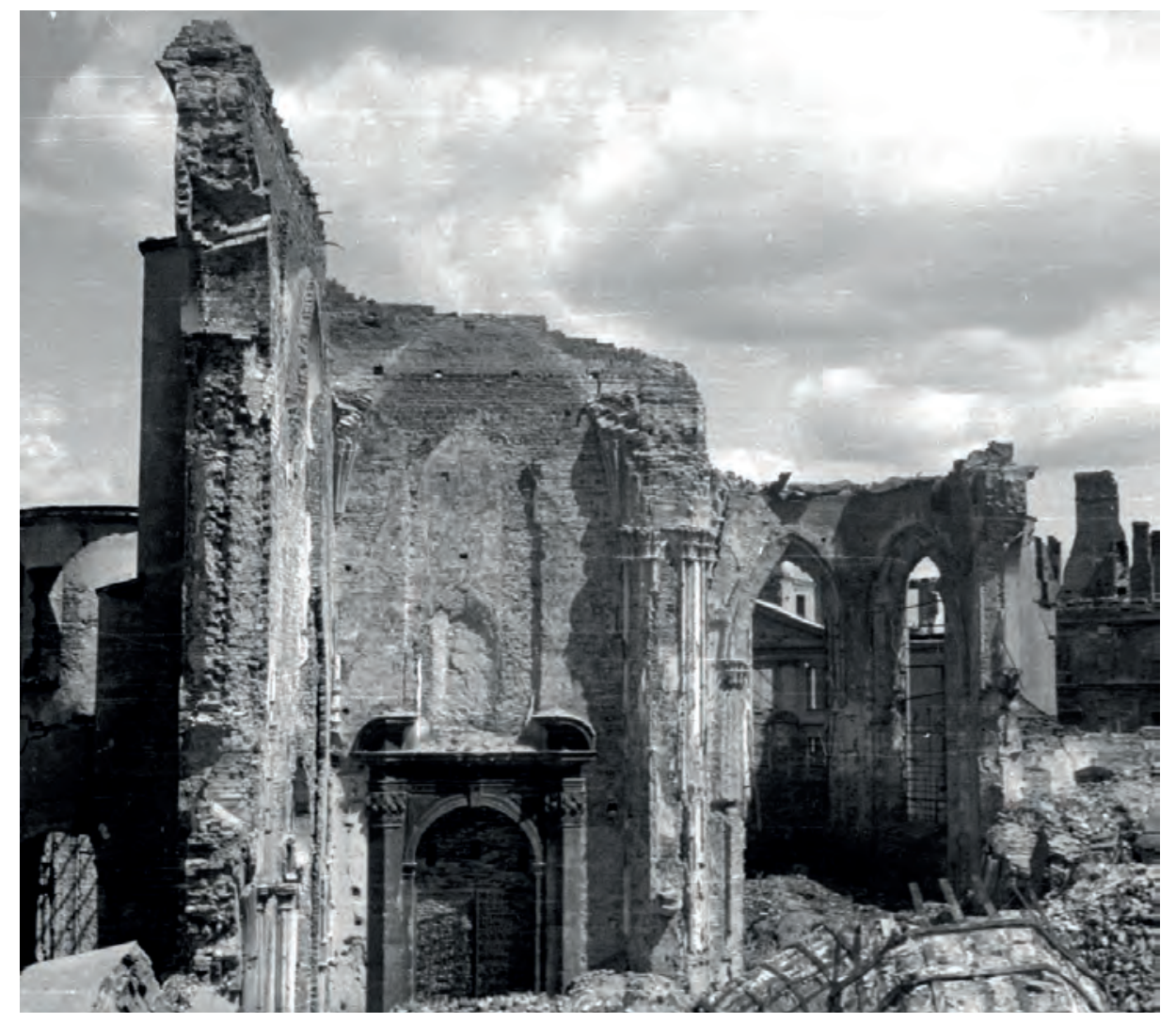

10. Warszawa, katedra św. Jana, widok na portal kaplicy Baryczkowskiej, ok. 1945, fot. domena publiczna

$* * *$

Łowicka kaplica Ukrzyżowania posiada młodszą genezę. Ubożej prezentuje się zarówno zasób zachowanych archiwaliów dotyczących jej powstania ${ }^{94}$, jak i stan badań $^{95}$. Okoliczności powstania oraz forma artystyczna sprawiają jednak, że jest wybitnym przykładem osiemnastowiecznego mauzoleum o wystroju przyrównywanym przez historyków sztuki do wnętrz rezydencjonalnych - buduaru bądź salonu' ${ }^{96}$.

\footnotetext{
94 Wzmianki o budowie kaplicy i przylegającej do niej zakrystii widnieją w księgach z Archiwum Diecezjalnego w Łowiczu (ADŁ, t. 1-4, passim), pojawiając się jako wyodrębnione noty (Expensarum Fabica Sacristiae et Capellae Komorovianae Calculus, Massa Komoroviana lub Expensa pro Fabrica, et Sacristia) bądź jako wydatki w ramach innych działów (np. Expensa Extraordinaria). Za udostępnienie woluminów pragniemy podziękować ks. Stanisławowi Majkutowi.

95 Całościową próbę spojrzenia na kaplicę podjęli kolejno: WIETESKA 1985, s. 4-5; GAJEWSKI 1986, s. 561-574; CZYŻ 2010, s. 113-166.

96 LoRENTZ 1966, s. 186-187; LORENTZ 1981, s. 32-33; GAJEWSKI 1986, s. 564.
} 
Kaplica została wzniesiona na mocy zapisu testamentowego prymasa Adama Ignacego Komorowskiego h. Korczak ${ }^{97}$ z 1 lutego 1759 roku $^{98}$. Duchowny zmarł w Skierniewicach 2 marca ${ }^{99}$, miesiąc po sporządzeniu dokumentu, którego koegzekutorami zostali: biskup chełmiński i kanonik łowicki Andrzej Bajer, kasztelan chełmiński Ignacy Komorowski ${ }^{100}$ (brat świętej pamięci arcybiskupa gnieźnieńskiego) oraz kanonicy, wśród których znaleźli się m.in. Paweł Kosicki i Michał Awedyk ${ }^{101}$. Ostatniemu z wymienionych księży przypadła wiodąca rola w realizacji postanowień, spośród których główną kwestią było przeznaczenie 20000 złotych na budowę mauzoleum ${ }^{102}$. Początkowo planowano zaaranżować na kaplicę Pana Jezusa Ukrzyżowanego dawną zakrystię prałacką i kapitularz ${ }^{103}$, ostatecznie jednak ograniczono się do przebudowy pierwszego z wymienionych pomieszczeń ${ }^{104}$. Wybór lokalizacji nie pozostawał przypadkowy - warunkowała go tradycja miejsca kultu szesnastowiecznego krucyfiksu ${ }^{105}$. Komorowski chcąc być pochowanym tam, gdzie ołtarz S. Crucis ${ }^{106}$, włączył słynącą łaskami rzeźbę w program ideowy wnętrza. Mauzoleum powstało na przedłużeniu nawy bocznej, po północnej stronie prezbiterium, stanowiąc przeciwwagę dla przylegającej do południowej ściany chóru kaplicy św. Wiktorii (Jakuba Uchańskiego) ${ }^{107}$. Nie bez znaczenia była też wizualna korespondencja z kaplicą Najświętszego Sakramentu (prymasa Jana Lipskiego) ${ }^{108}$. Prace architektoniczne prowadzono od 1760 roku, w pierwszej kolejności wznosząc nową zakrystię

\footnotetext{
97 Informacje o ostatnich latach życia i okolicznościach śmierci Komorowskiego znaleźć można m.in. w zasobach: AGAD, AWR, sygn. 7041, passim; AGAD, ZAPB, sygn. 1214, passim.

98 Arcybiskup gnieźnieński wobec pogarszającego się stanu własnego zdrowia (AGAD, ZAPB, sygn. 1214, s. 2) miał świadomość, że osobiście nie zdąży rozpocząć inwestycji. Z tego względu zdecydował się na „zabezpieczenie” przyszłości budowy planowanej kaplicy w testamencie (ADE, t. 4).

99 AGAD, ZAPB, sygn. 1214, s. 1-2; ADŁ, t. 4; WIETESKA 1985, s. 2; MrOZOWSKi 2003, s. 175; OCZYKOWSKI 2020, s. 96.

100 ADE, t. 4.

101 Ibidem; WIETESKA 1985, s. 4; GAJEWSKI 1986, s. 561, 574.

102 AGAD, ZAPB, sygn. 1214, s. 3. W Łowiczu pochowano ciało prymasa, natomiast serce zmarłego spoczęło w farze w Skierniewicach, zob. ADŁ, t. 4; WiETESKA 1985, s. 2.

103 ADE, t. 2, s. 373, 412; GAJEWSKi 1986, s. 561.

104 ADE, t. 2, s. 456.

105 CZYŻ 2010, s. 114; OCZYKOWSKI 2020, s. 86.

106 ADE, t. 4; WIETESKA 1985, s. 4.

107 Szesnastowieczna kaplica Uchańskiego została przebudowana w duchu klasycyzmu z inicjatywy biskupa Kajetana Sołtyka w latach 1782-1783. Pracami kierował Efraim Szreger. W portalu nawiązano do oprawy wejścia wiodącego do mauzoleum Komorowskiego, wprowadzając profilowaną, czarnomarmurową arkadę. Walory dekoracyjne zapewniono poprzez stiukową kotarę, zob. Czyż 2010, s. 81-85.

108 Ideowa wymowa lokalizacji kaplicy została przedstawiona w tekście: GAJEwSKI 1986, s. $564-571$.
} 
(tzw. kanonicką) ${ }^{109}$. W 1761 roku rozpoczęto budowę mauzoleum ${ }^{110}$ i zdołano doprowadzić do końca większość prac murarskich ${ }^{111}$. Archiwalia kapituły z tego okresu oraz trzech kolejnych lat dokumentują inwestycję. Nie odnotowano w nich wprawdzie nazwisk architektów ani kwestii estetycznych, ograniczając się jedynie do zapisków czysto finansowych - ekspens czynionych: pro fabrica capellae ${ }^{112}$ czy ad massam Komorovianam ${ }^{113}$, takich jak zakup materiałów: drewna, wapna, gipsu ${ }^{114}$. Oficjalne zakończenie prac przy kaplicy nastąpiło w 1764 roku, w którym do wnętrza przeniesiono trumnę prymasa, a 12 grudnia sesja kapitulna przyjęła sprawozdanie z poniesionych kosztów ${ }^{115}$. Zwieńczeniem inwestycji było pokrycie dachu miedzianą blachą w 1765 roku$^{116}$.

Wyjątkowo cennych informacji o etapach prac nad wystrojem kaplicy dostarczają archiwalia klasztoru Karmelitów w Czernej - wspomnianego wcześniej dysponenta "marmuru” dębnickiego ${ }^{117}$. Odnotowane w nich olbory jednoznacznie dowodzą, że nagrobek fundatora zaczęto przygotowywać równolegle z pracami budowlanymi, a nie po ukończeniu fazy architektonicznej. Już w daninach od wydobytego kruszcu za listopad i grudzień 1761 roku uwzględniono 606 florenów za epitafium, którym miał zostać upamiętniony Celessimus Primatus ${ }^{118}$. W kolejnym roku wymieniono co najmniej trzy kolejne sumy: ponad 950 florenów w marcu ${ }^{119}$ i po 600 florenów w zestawieniach za czerwiec i lipiec ${ }^{120}$ oraz listopad i grudzień ${ }^{121}$.

109 ADE, t. 2, s. 530; CZYż 2010, s. 76. Konieczność budowy nowej zakrystii po południowej stronie prezbiterium była warunkowana przez decyzję o zaadaptowaniu na mauzoleum wcześniejszego pomieszczenia o tej funkcji. Przyjmuje się, że zakrystię w zasadniczej części ukończono w ciągu roku, lecz w księdze wydatków odnotowywano sumy płacone za materiały budowlane (w tym za wapno i dębowe tarcice) do roku 1764, zob. ADŁ, t. 3, s. 251, 263; WIETESKA 1985, s. 5.

110 ADŁ, t. 1, s. 15.

111 Ibidem, s. 31; ADŁ, t. 3, s. 282; LORENTZ 1966, s. 185-186; GAJEWSKI 1986, s. 561.

112 ADŁ, t. 1, k. 174; ADŁ, t. 3, s. 251, 263, 278-279, 282.

$113 \mathrm{AD}$, t. 3, s. 250. Część pieniędzy z funduszu Komorowskiego przeznaczano też na inne cele związane z codziennym funkcjonowaniem kapituły - np. na zakup arkuszy papieru lub oprawę ksiąg, zob. ADŁ, t. 2, s. 540-541.

114 ADE, t. 3, s. 251, 263.

115 ADE, t. 1, s. 174; LORENTz 1966, s. 186. Razem z kaplicą rozliczano oczywiście zakrystię.

116 Kotlarz otrzymał wówczas wynagrodzenie od dokończenia dachu miedzia pobijania, zob. ADE, t. 3, s. 278-279.

117 WANAT 1992, s. 35-40; GraCZyK/MARSZTALSKA 2014, s. 73-75; WARDZYŃSKi 2015a, s. 275-280, 293-294; SKRABSKI 2016, passim.

118 APKBCz, sygn. 324, k. 185v.

119 Ibidem, k. $187 \mathrm{v}$.

120 Ibidem, k. 190v.

121 Ibidem, k. 192v. Kolegiaty dotyczyła też wzmianka o kwocie pobranej za posadzkę, zaksięgowanej za kwartał marzec-maj 1764 roku jako: Olbora a pavimento Ecclesia Eovicensis (ibidem, k. 198v). 
W łowickim mauzoleum wprowadzono bardzo przemyślaną koncepcję artystyczno-ideową, tworzącą wrażenie wewnętrznej spójności całej przestrzeni, a zarazem korespondencji z pozostałymi partiami kolegiaty ${ }^{122}$. Od zewnątrz kaplica prymasa nie wyodrębnia się w sposób czytelny, tworząc wraz z zakrystią wikariuszy spójną bryłę (il. 11). O szczególnym przeznaczeniu tej partii świątyni świadczy jedynie wysokie, półkoliście zamknięte okno zwieńczone kompozycją z herbem Korczak $^{123}$. Kaplica otrzymała plan prostokąta $z$ dwoma zaokrąglonymi narożnikami po stronie wschodniej ${ }^{124}$. Wysoką arkadę wejściową ujęto profilowaną opaską odkutą w dębniku i zwieńczoną stiukowymi figurami aniołów. Forma portalu, dość minimalistyczna w swym charakterze, miała na celu wyeksponowanie widoku na ołtarz mieszczący cudowny krucyfiks. Jak wykazał Jacek Gajewski, jedną z przyczyn architektonicznych wyborów było dostosowanie do rytmu codziennej liturgii - msze i modlitwy rozpoczynano rano przy głównej nastawie kolegiaty, a następnie odprawiano kolejno przy ołtarzach: Najświętszego Sakramentu i Jezusa Ukrzyżowanego. Tym samym wierni znajdujący się przed kaplicą Lipskich mogli dostrzec kolejny punkt wewnątrzświątynnej procesji ${ }^{125}$. Jednocześnie krata wydzielająca mauzoleum Komorowskiego - ukoronowana monogramem prymasa i mitrą książęcą ${ }^{126}$ - od razu wskazywała na osobę, której szesnastowieczna figura zawdzięcza godną oprawę $e^{127}$. Kaplica posiada pełną artykulację z wysokim cokołem i belkowaniem wspartym na korynckich pilastrach. Kolebkowe sklepienie w części wschodniej, ponad nastawą ołtarzową przechodzi w konchę. W zaokrąglone narożniki wpisano skrzydła drzwiowe, nad którymi widnieją wsparte na konsolach, przeszklone loże zamknięte od frontu wklęsło-wypukłą balustradą ${ }^{128}$. Tego rodzaju kompozycje, wstawione między podpory, wprowadzono w sztuce warszawskiej np. w prezbiterium kościoła Wizytek (il. 12), aranżowanym w drugiej połowie lat 50. XVIII wieku przez Johanna Georga Plerscha wedle projektu Jakuba Fontany ${ }^{129}$. Ołtarzowi nadano formę

\footnotetext{
122 GAJEWSKi 1986, s. 264-265, 269.

123 LORENTZ 1966, s. 186; CZYŻ 2010, s. 23.

124 CZYŻ 2010, s. 113.

125 GAJEWSKi 1986, s. 564.

126 LORENTZ 1966, s. 186.

127 Szerokość arkady uniemożliwia jednak dostrzeżenie bocznych ścian mauzoleum zawierających w sobie okno (od północy) i nagrobek fundatora (od południa). By je dostrzec, konieczne jest zbliżenie się do kraty.

128 Północna loża pod względem funkcjonalnym jest niewielkim oknem, które stanowi drugie źródło naturalnego światła.

129 U wizytek pod lożami umieszczono relikwiarze unoszone przez putta, zob. SITO 2013, s. 236, 293. W Łowiczu ich reminiscencją są postacie aniołków flankujących ołtarz - zwłaszcza figura po północnej stronie nastawy, podtrzymująca balustradę loży. Interesującym wątkiem jest też obecność analogicznych kompozycji w elewacjach zewnętrznych - również w omawianym kościele Wizytek pw. Opieki św. Józefa, zob. Bernatowicz 2016, s. 45.
} 
TECHNE

T E X N H

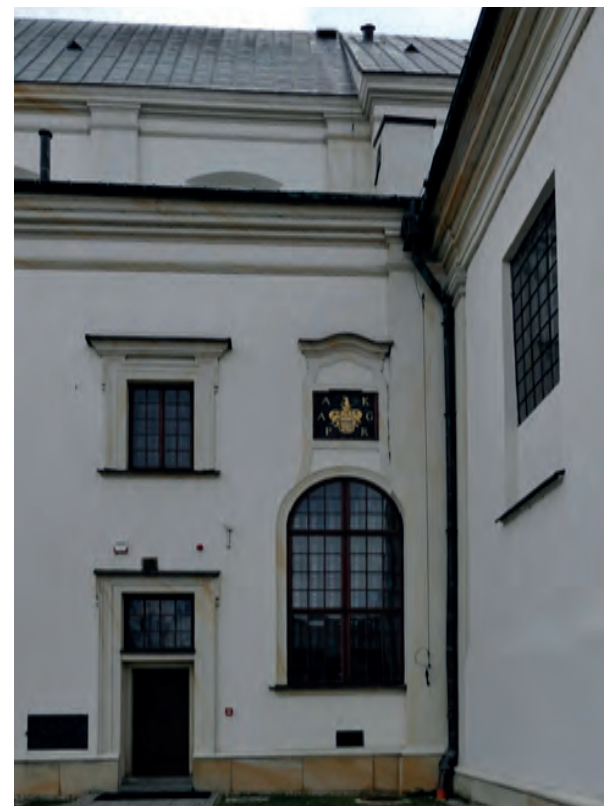

11. Łowicz, kolegiata Wniebowzięcia NMP, kaplica Komorowskiego, fot. autorka, 2019
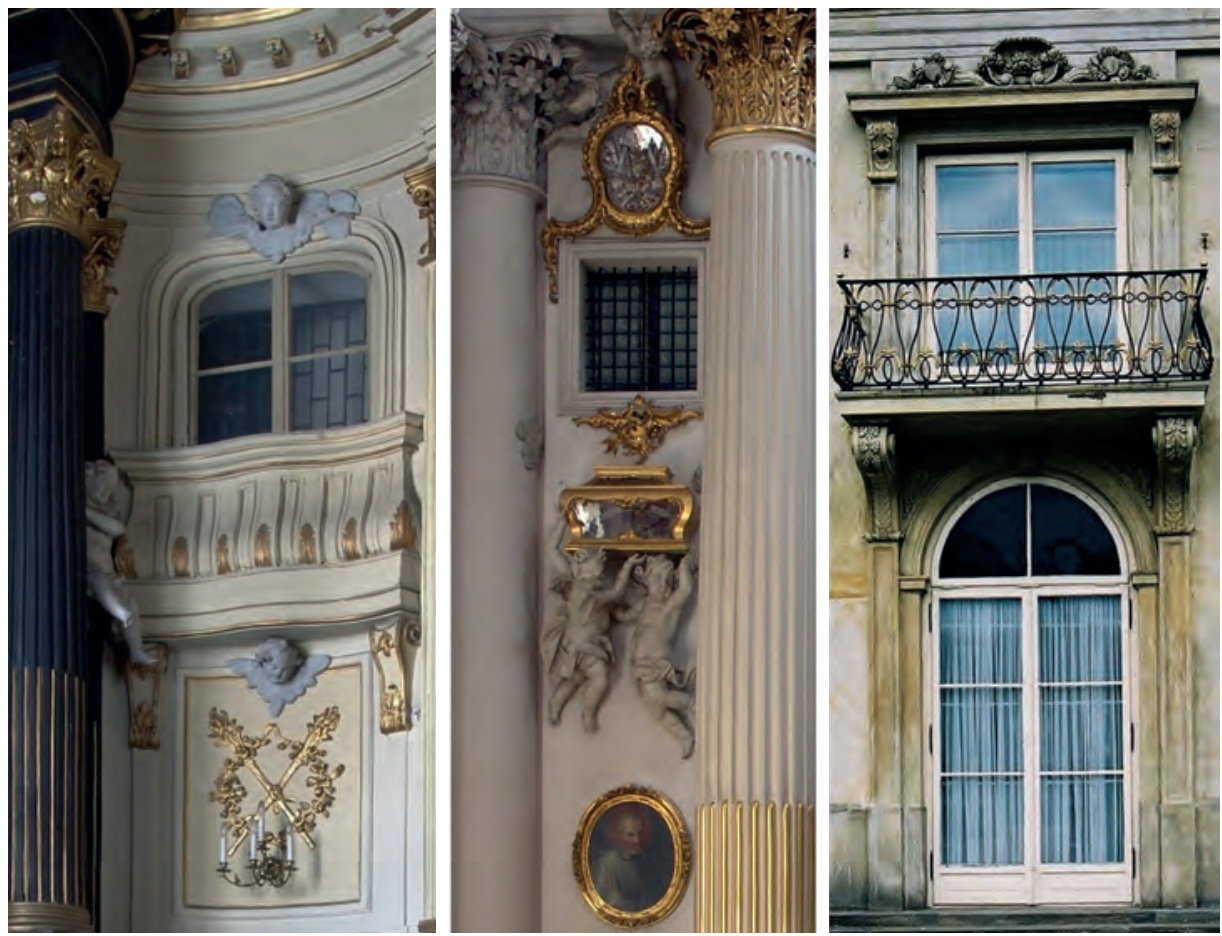

12. Od lewej: a) Łowicz, kolegiata Wniebowzięcia NMP, kaplica Komorowskiego - detal, fot. autorka, 2019; b) Warszawa, kościół Wizytek, ściana szczytowa prezbiterium - detal, fot. autor, 2019; c) Warszawa, pałac Na Wyspie, elewacja południowa - detal, fot. autor, 2017 


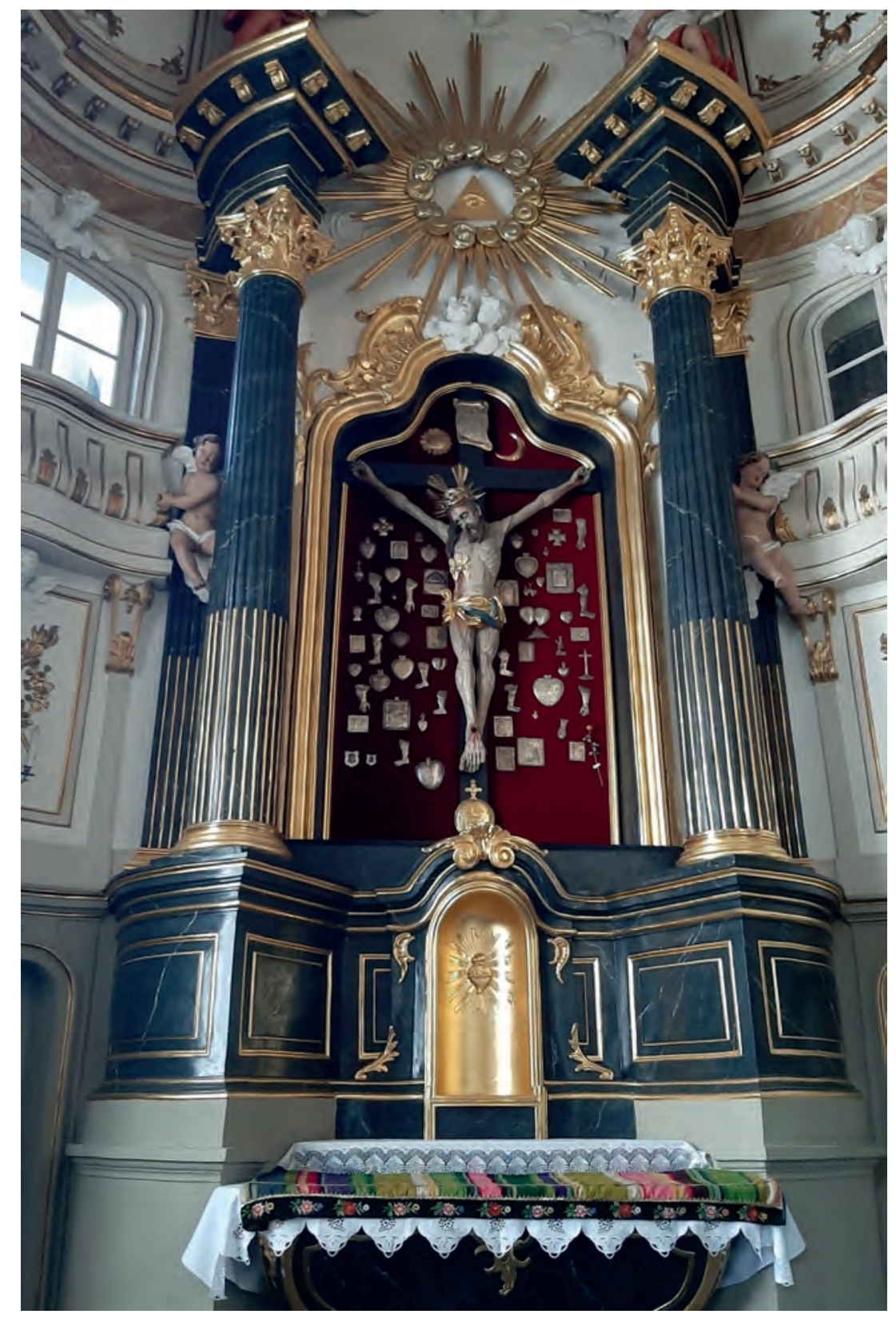

13. Łowicz, kolegiata Wniebowzięcia NMP, ołtarz w kaplicy Komorowskiego, fot. autorka, 2019

jednoosiową, zintegrowaną z artykulacją ścian kaplicy i uzasadniającą znaczną wysokość obiegającego wnętrze cokołu. Nastawę wymurowano na rzucie przerwanego owalu, z dynamicznie kształtowanymi, silnie akcentującymi przestrzeń kolumnami dźwigającymi wydatne wycinki belkowania, na których przyklękają figury aniołów (il. 13). Podpory nadają dziełu charakter architektoniczny, mimo iż partia środkowa 
jest w pełni ażurowa. W centralnym polu ołtarza widnieje złocona rama, w której, na tle czerwonej tkaniny, zawieszony jest szesnastowieczny krucyfiks w otoczeniu licznych wotów. Powyżej, w partii zwieńczenia widnieje promienista gloria z Okiem Opatrzności. Ekspresja form założonych na rzucie eliptycznym przywodzi na myśl kompozycje zastosowane we wcześniej scharakteryzowanych obiektach z pierwszej ćwierci XVII wieku. Z realizacji warszawskich przywołać można oprawę pomnika książąt mazowieckich, nagrobek Radziejowskiego z kościoła św. Krzyża i oczywiście ołtarz Baryczkowski z warszawskiej kolegiaty św. Jana ${ }^{130}$. Nawiązanie do stołecznej nastawy wydaje się w tym przypadku świadomym zabiegiem włączającym jednocześnie ołtarz fundacji Komorowskiego w tradycję włoską ${ }^{131}$. Wrażenie redukcji form architektonicznych łowickiego ołtarza i sprowadzenia centralnej części do ramy z krzyżem oraz glorii stało się jeszcze silniejsze po 1888 roku, gdy boczne partie nastawy (cokół, pilastry i kolumny, belkowanie) pomalowano na czarno ${ }^{132}$.

W oryginalnej postaci wnętrze utrzymane było w biało-złotej kolorystyce. Wyjątek stanowiły: okno wybite w ścianie północnej, ujęte obramieniem z dębnika, oraz monument Adama Ignacego Komorowskiego o strukturze wykonanej $\mathrm{z}$ tego samego wapienia ${ }^{133}$. Z czarnym tłem nagrobka kontrastują partie odkute w marmurze kararyjskim (w tym zwłaszcza motywy figuralne) i mosiężne detale ${ }^{134}$. Autorem rzeźb z pomnika był jeden z najwybitniejszych rzeźbiarzy tego okresu, Johann Chrisostomus Redtler ${ }^{135}$, przypuszczalnie realizujący projekt Jakuba Fontany i Domenica Merliniego, do czego przyjdzie nam jeszcze powrócić. Nagrobek wmontowano w południowe przęsło kaplicy, naprzeciwko półkoliście zamkniętego okna, którego odpowiednik można dostrzec w arkadzie wpisanej w centralną część pomnika (il. 14). Oba dzieła ozdobiono też agrafą z motywem uskrzydlonej czaszki. W niszy, na prostokątnej tablicy inskrypcyjnej stoi sarkofag na lwich łapach, zdobiony kompozycją heraldyczną. Największym znaczeniem artystycznym i ideowym obdarzono grupę figuralną usytuowaną na tumbie i odkutą w marmurze z Carrary ${ }^{136}$. Owalny medalion z reliefowym portretem Komorowskiego podtrzymują dwa putta. Pierwsze $\mathrm{z}$ nich, ukazane $\mathrm{w}$ pozycji stojącej, trzyma mosiężny wieniec laurowy

\footnotetext{
130 KwiatKowska 1978, s. 104-106; NieciecKi 1997, s. 9-11.

131 Raz jeszcze przywołać warto chociażby postać Andrei Pozza, który wytyczył jedną z głównych linii rozwojowych struktur na rzucie eliptycznym, zob. Pozzo 1700, passim; Bania 2018, s. $134-141$.

132 GAJEWSKi 1986, s. 564, przyp. 227.

133 KZSP 1954, s. 138; Miкоска-RACHUbоwa 2007, s. 270.

134 SiTO 2009, s. 415, 418 .

135 KZSP 1954, s. 138; Lorentz 1966, s. 186-187; Lorentz 1981, s. 32-33; MiкоcKa-RACHUBOWA 2007, s. 270; GAJEWSKI 2012, s. 84; WARDZYŃSKI 2015b, s. 703. Redtler (wraz z kamieniarzem Michaelem Dolingerem) wykonał też nagrobek serca Komorowskiego, które złożono w farze w Skierniewicach, zob. ADŁ, t. 4; WIETESKA 1985, s. 2.

136 KZSP 1954, s. 138; MiкоскA-Rachubowa 2007, s. 270; Sito 2009, s. 418.
} 


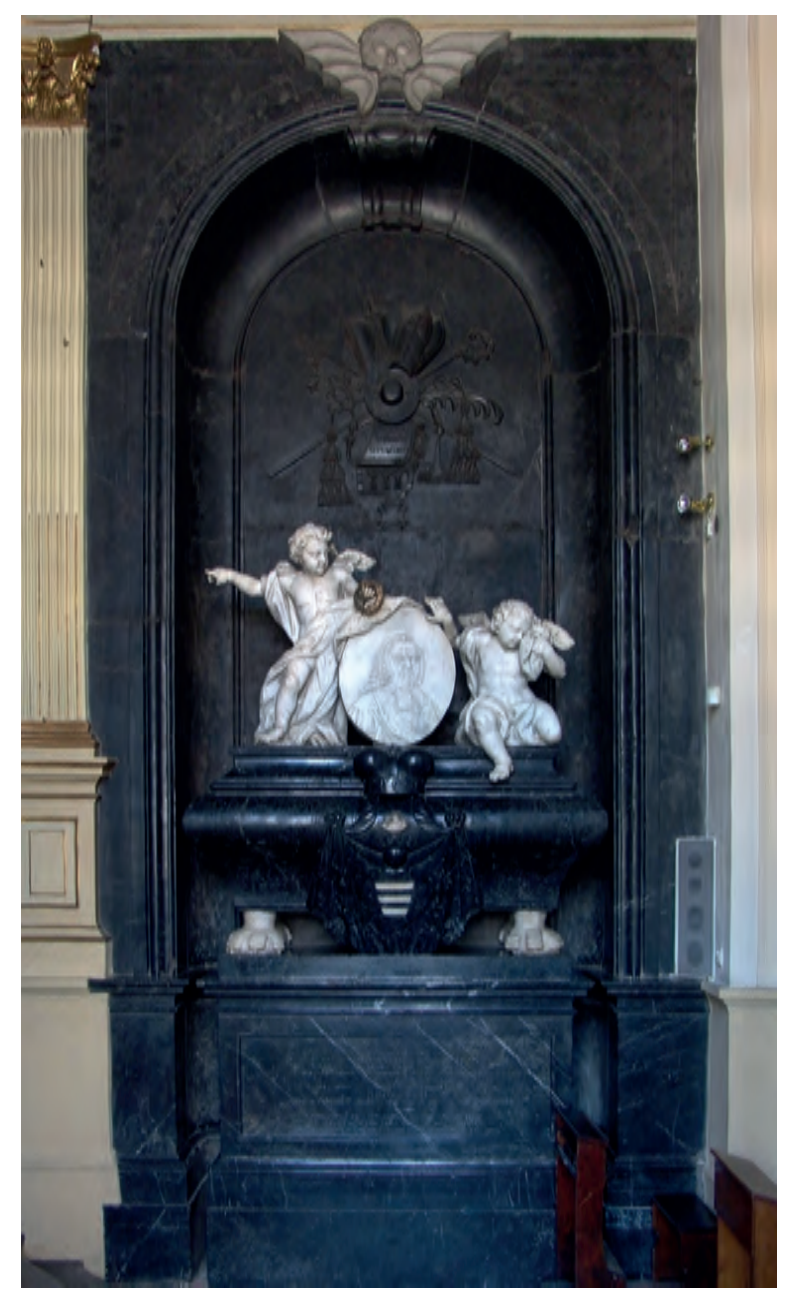

14. Łowicz, kolegiata Wniebowzięcia NMP, nagrobek prymasa Komorowskiego, fot. autor, 2019

i prawą dłonią wskazuje na słynący łaskami krucyfiks. Drugie natomiast (słabsze pod względem jakości wykonania ${ }^{137}$ ), siedząc przy portrecie prymasa, rozpacza i ociera chustką łzy. Na podkreślenie zasługuje precyzja dostosowania wymiarów, formy i programu symbolicznego nagrobka do kontekstu przestrzennego kaplicy, od początku uwzględnianego w projekcie architektonicznym i odkuwanego na wczesnym etapie prac nad jej wystrojem, co potwierdzają wyżej wspomniane olbory klasztoru w Czernej ${ }^{138}$. Wniosek ten prowadzi do konieczności ponownego rozważenia kwestii autorstwa koncepcji wystroju.

\footnotetext{
137 Zapewne figura ta pochodzi spod dłuta jednego ze współpracowników Redtlera należących do jego warsztatu.

138 APKBCz, sygn. 324, k. 185v, 187v, 190v, 192v.
} 
Próby atrybucji kaplicy przez długi czas pozostawały przedmiotem dywagacji badaczy. Początkowo za autora projektu uważano architekta królewskiego Efraima Szregera vel Schrögera ${ }^{139}$, a następnie włączono łowickie dzieło do oeuvre Franciszka Placidiego ${ }^{140}$. Weryfikacji hipotez dokonał wreszcie Jacek Gajewski, który na podstawie wnikliwej analizy formalnej i faktograficznej ${ }^{141}$ przypisał kaplicę Jakubowi Fontanie $^{142}$. Projekt mauzoleum wpisywał się w przełom dwóch faz twórczości królewskiego architekta, dojrzałej i późnej, między którymi cezura przypadła właśnie na lata 60. XVIII stulecia ${ }^{143}$. Artykulacja kaplicy Komorowskiego wykazuje zbieżność zarówno z dziełami z lat 50., jak i z rozwiązaniami wprowadzanymi przez twórcę do innych dzieł warszawskich z siódmej dekady, przykładowo z wystrojem Sali Mirowskiej na Zamku Królewskim ${ }^{144}$. W odniesieniu do Łowicza powszechnie przyjęto tezę o autorstwie Jakuba Fontany ${ }^{145}$. Atrybucja nie wzbudza wątpliwości, możliwe jest jednak jej rozszerzenie. Wydaje się bardzo prawdopodobne, że udział w realizacji prymasowskiego mauzoleum miał pochodzący z Mendrisio Domenico Merlini. Za możliwością zaangażowania tego włoskiego twórcy przemawia parę argumentów. Pierwszym z nich jest potwierdzona źródłowo obecność Merliniego w zespole architektonicznym Fontany, u którego zdobywał doświadczenie m.in. jako uczeń, kierownik budowy i kreślarz ${ }^{146}$. Mimo coraz większej samodzielności ${ }^{147}$ pozostawał stałym współpracownikiem swojego mistrza - obaj Włosi odnotowani zostali np. przy wznoszeniu korpusu i elewacji kościoła Kamedułów na warszawskich Bielanach (w latach 1749-1763) ${ }^{148}$ oraz przy wyżej omówionej przebudowie kaplicy Baryczkowskiej (w latach 1761-1762) ${ }^{149}$. Po śmierci Fontany w 1773 roku Merlini

\footnotetext{
139 LORENTZ 1966, s. 182.

140 LORENTZ 1981, s. 27; WIETESKA 1985, s. 4.

141 Jak udało się ustalić, jeden z członków kapituły odpowiedzialnej za realizację postanowień z testamentu Komorowskiego (i tym samym za budowę kaplicy), kanonik Adam Zajączkowski, regularnie utrzymywał kontakty z Jakubem Fontaną w czasie, gdy prowadzono inwestycję, zob. GAJEWSKI 1986, s. 574.

142 GAJEWSKi 1986, s. 571.

143 BARTCZAKOWA 1970, s. 203-206; GAJEWSKi 1986, s. 573.

144 Sala przeznaczona dla królewskiej gwardii przybocznej zyskała nowy wystrój za sprawą Fontany w 1768 roku. Artykulację utworzyły kompozytowe pilastry i płyciny, a fryz ozdobiono stiukowymi girlandami, zob. BARTCZAKOWA 1970, s. 233-236; KWIATKOWSKI 1983, s. 59-60; GAJEWSKI 1986, s. $573-574$.

145 CZYŻ 2010, s. 113

146 TATARKiEWICZ 1955, s. 5-6; WÁtroba 2016, s. 314-315.

147 Potwierdzeniem sukcesów zawodowych może być status majątkowy Merliniego, który w 1759 roku, w wieku 29 lat, postanowił odkupić cegielnię Giuseppego Antonia Affaitatiego na Mokotowie, zob. WĄTROBA 2016, s. 314.

148 ŁUGOWSKI 2016, s. 143, 145-147; WĄTROBA 2016, s. 314, 316.

149 AGAD, A. Ros., sygn. XIII 63, k. 1; AGAD, A. Ros., sygn. XI 66, s. 533; WĄTrobA 2016, s. 314,316 .
} 

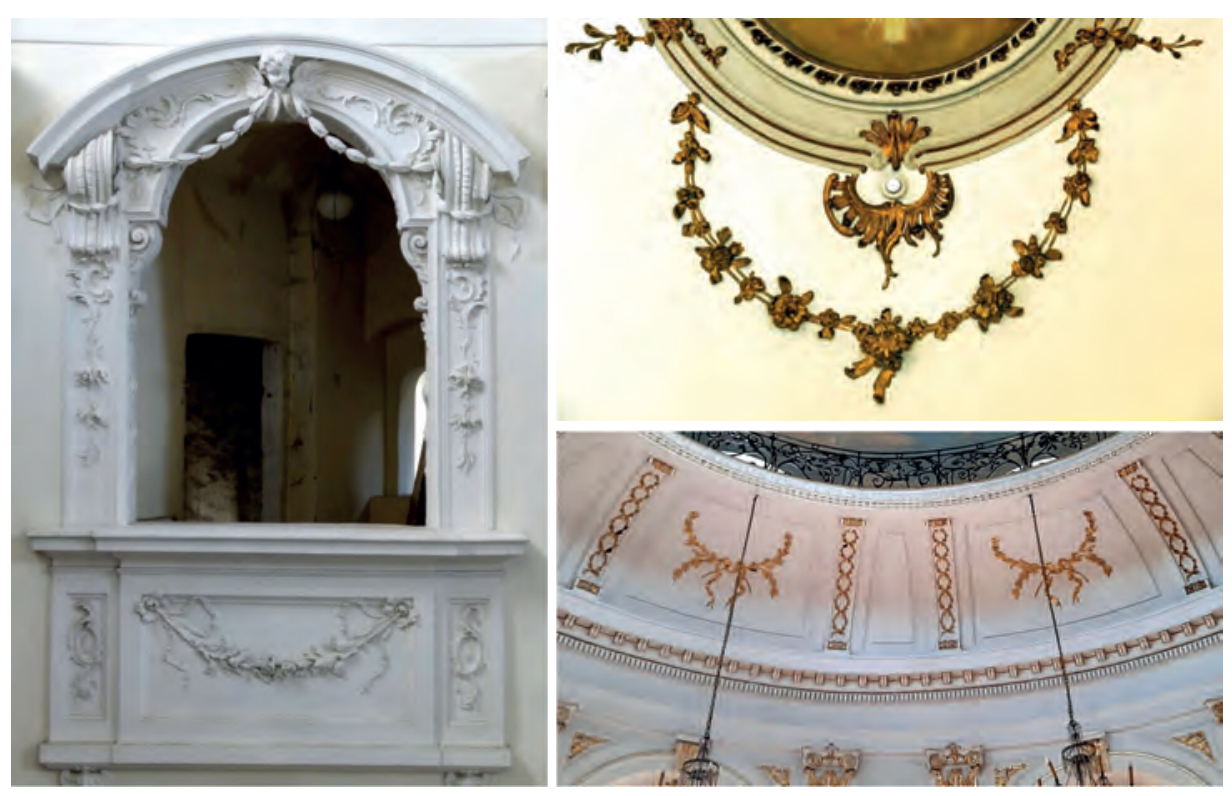

15. Od lewej: a) Warszawa, kościół Kamedułów na Bielanach, transept - detal, fot. autor, 2019;

b) Łowicz, kolegiata Wniebowzięcia NMP, kaplica Komorowskiego, sklepienie - detal, fot. autor, 2019;

c) Jabłonna, pałac Poniatowskich, sala balowa - detal, fot. autorka, 2020

stał się jego następcą w znaczeniu dosłownym - przejmując stanowisko Architekta Króla i Rzeczypospolitej ${ }^{150}$ - oraz przenośnym, wynikającym z częściowej kontynuacji drogi artystycznej swego poprzednika i nauczyciela. W realizacjach Merliniowskich można dostrzec elementy stojące na pograniczu epok, wkraczające w klasycyzm, lecz nadal niepozbawione rokokowej lekkości i subtelności detali. Zestawienie potwierdzonych dzieł tego twórcy z kaplicą w Łowiczu uwidacznia czytelne analogie - narożne loże przywodzą na myśl sposób opracowania artykulacji balkonowej z projektu pałacu Na Wyspie ${ }^{151}$, a złocone detale ornamentalne (wieńce, girlandy na sklepieniu) mają swe odpowiedniki w wystroju sali balowej rezydencji w Jabłonnej ${ }^{152}$ oraz przezroczu transeptu kościoła Kamedułów na Bielanach (il. 15) ${ }^{153}$. Wymienione motywy nie są wprawdzie identyczne, ale niewykluczone, że u źródeł ich powstania leży wspólna geneza. W konsekwencji można postawić hipotezę o współpracy Merliniego z Fontaną przy budowie kaplicy Komorowskiego. Obaj architekci prawdopodobnie byli też odpowiedzialni za projekt nagrobka wykonanego przez Johanna Chrisostoma Redtlera ${ }^{154}$ i stanowiącego integralną część architektury wnętrza.

\footnotetext{
150 TAtarkiewicz 1955, s. 6; WĄTroba 2016, s. 314-315.

151 TATARKIEWICZ 1955, s. 27, 89, il. 67.

152 Ibidem, s. 24-26, 128, il. 117, 130, il. 119.

153 Realizowanego przez obu omawianych architektów, zob. WĄTrOBA 2016, s. 314.

154 MikocKA-RACHUBOWA 2007, s. 270; WARDZYŃSKi 2015b, s. 703.
} 
Scharakteryzowane kaplice wykazują różnice w zasadniczym czasie powstania - odległym od siebie o pół wieku - a także w szczegółowych rozwiązaniach zastosowanych w trakcie budowy (Łowicz) i przebudowy (Warszawa) z początku lat 60 . XVIII stulecia. Wiele cech łączy jednak ze sobą te dwa wybitne dzieła. Poza kwestiami czysto formalnymi, takimi jak status obu świątyń kolegiackich i kontakty utrzymywane między obiema kapitułami, należy w pierwszej kolejności spojrzeć na funkcje obiektów. Zarówno kaplicę Baryczkowską, jak i mauzoleum Adama Ignacego Komorowskiego ukształtowano jako monumentalną, architektoniczną oprawę dla figury Chrystusa Ukrzyżowanego ${ }^{155}$, z teologicznego punktu widzenia stanowiącej główną, duchową oś całej przestrzeni. Krucyfiksy wyznaczyły centralne punkty zarówno na płaszczyźnie religijnej, jak i stricte artystycznej. Zostały umieszczone w głównych kondygnacjach ołtarzy w sposób, który pozwala na ich obserwację już z nawy, a efekty scenograficzne wzmożono przez korespondujące z ołtarzami portale. Kluczowa rola w powstaniu obu kaplic przypadła hierarchom kościelnym doskonale zorientowanym w roli sztuki i mającym ambicje mecenasowskie ${ }^{156}$. Jan Klemens Branicki nie ustępował pod względem zainteresowań artystycznych Szembekowi i Komorowskiemu ${ }^{157}$, co pozwoliło na wprowadzenie interesujących i unikatowych form w trakcie modernizacji warszawskiej budowli ${ }^{158}$. Najważniejszym zagadnieniem, na które w podsumowaniu niniejszego tekstu chcielibyśmy zwrócić uwagę, są jednak zależności konkretnych rozwiązań artystycznych. Stołeczna kaplica wywarła bowiem wpływ na swój młodszy, łowicki odpowiednik. Wzajemne powiązania z pewnością stanowiły efekt zaangażowania do obu realizacji tych samych, królewskich architektów, odznaczających się wybitnym zmysłem projektowym. Z Warszawy nastąpiła transpozycja formy ołtarza na rzucie owalnym, zaczerpniętej z projektów Pozza i spopularyzowanej w drugiej i trzeciej dekadzie stulecia ${ }^{159}$ - tym ciekawsze jest powtórzenie tej koncepcji na początku lat 60. Jednocześnie w redakcji formy uwidoczniła się obecna w tym okresie tendencja do redukcji form architektonicznych - zastosowana dość subtelnie, jedynie w centralnej partii nastawy, lecz poświadczająca próbę dynamizacji i unifikacji ołtarza

\footnotetext{
155 AAW, sygn. WG-2, s. 85-86; CZYŻ 2010, s. 114.

156 KWIATKOWSKI 1939, passim; WIETESKA 1985, passim; GAJEWSKI 1986, passim; SWĘDROWSKI 2012, s. 345-346, 357.

157 Postać hetmana należy do najlepiej rozpoznanych mecenasów na gruncie historii sztuki. $\mathrm{Z}$ najważniejszych całościowych opracowań na temat podejmowanych przez Branickiego inicjatyw artystycznych przywołać należy przede wszystkim monografię Anny Oleńskiej (OLEŃsKA 2011, passim).

158 AGAD, A. Ros., sygn. XI 66, k. 546-547, 553, 557.

159 BANIA 2018, passim.
} 
$\mathrm{z}$ resztą wystroju. $\mathrm{W}$ obu obiektach pojawiły się wpływy architektury pałacowej, przejawiające się w zapożyczaniu poszczególnych elementów (łuku koszowego, płycin z motywami dekoracyjnymi, kształtu balkonów), lekkości form, rokokowej stylistyce i kolorystyce opartej na łączeniu bieli ze złotem. Z wnętrzami rezydencjonalnymi musiały kojarzyć się zwłaszcza obicia ścian wprowadzone przez Fontanę w obecnej katedrze św. Jana ${ }^{160}$. Łowickie mauzoleum wpisywało się ponadto w moment przejściowy między późnym barokiem i rokokiem a klasycyzmem ${ }^{161}$.

Zaprezentowania analiza pozwoliła na doprecyzowanie dotychczasowych ustaleń, a także ukazanie procesu budowy oraz przekształceń omawianych obiektów. Spojrzenie na ich formę architektoniczną i detale wystroju umożliwiło wskazanie źródeł inspiracji, prawdopodobnych wykonawców oraz poświadczenie zależności pomiędzy dwoma szczególnie ważnymi przykładami osiemnastowiecznych kaplic kolegiackich.

\section{Bibliografia}

\section{Źródła rękopiśmienne}

AAW, LB - Archiwum Archidiecezjalne Warszawskie, Liber baptizatorum, 1659-1668, s.n.

AAW, sygn. WG-2 - Archiwum Archidiecezjalne Warszawskie, Visitationes Ecclesiarum quae ipsemet Excellmus et Rmus Dnus Antonius Onuphrius de Okęcie Okęcki Episcopus Posnaniensis et Varsaviensis Supremus Regni Cancellarius, [1779-1784], sygn. WG-2.

ADŁ, t. 1 - Archiwum Diecezjalne w Łowiczu, Acta Capituli. Liber 9no, 1761-1778, s.n.

ADŁ, t. 2 - Archiwum Diecezjalne w Łowiczu, Liber Actorum Capituli Loviciensis, 1746-1761, s.n.

ADŁ, t. 3 - Archiwum Diecezjalne w Łowiczu, Ratio Proventuum et Expensarum Capituli Loviciensis, 1743-1801, s.n.

ADŁ, t. 4 - Archiwum Diecezjalne w Łowiczu, [Testament prymasa Adama Ignacego Komorowskiego], s.n.

AGAD, A. Ros., sygn. 11 - Archiwum Główne Akt Dawnych, Archiwum Roskie, Korespondencja Branickich. Jan Klemens Branicki do różnych, [suplement], sygn. 11.

AGAD, A. Ros., sygn. XI 66 - Archiwum Główne Akt Dawnych, Archiwum Roskie, Korespondencja do Branickiego Jana Klemensa, sygn. XI 66.

AGAD, A. Ros., sygn. XIII 63 - Archiwum Główne Akt Dawnych, Archiwum Roskie, Korespondencja do Branickiego Jana Klemensa, sygn. XIII 63.

AGAD, AWR, sygn. 7041 - Archiwum Główne Akt Dawnych, Archiwum Warszawskie Radziwiłłów, Komorowski Adam Ignacy, [korespondencja z lat 1748-1758], sygn. 7041.

\footnotetext{
160 AGAD, A. Ros., sygn. XI 66, k. 546-547, 553.

161 LORENTZ 1966, s. 186; CZYŻ 2010, s. 113-114.
} 
AGAD, ZAPB, sygn. 1214 - Archiwum Główne Akt Dawnych, Zbiór Anny z Potockich Ksawerowej Branickiej, Relacja śmierci prymasa Adama Komorowskiego, sygn. 1214, (dawna sygn. K/ I/1e, 1402).

ANK, ZDP, sygn. 410 - Archiwum Narodowe w Krakowie, Zbiór dokumentów papierowych, [Władysław IV, król polski, poleca magistratowi krakowskiemu przygotować miejsce na skład owsa [...], wysyłając owiesnego królewskiego Wojciecha Baryczkę], sygn. 410.

APKBCz, sygn. 323 - Archiwum Prowincji Karmelitów Bosych w Czernej, Liber Expensarum et Acceptarum, sygn. 323.

APKBCz, sygn. 324 - Archiwum Prowincji Karmelitów Bosych w Czernej, Liber Expensarum et Acceptarum, 1734-1765, sygn. 324.

\section{Źródła drukowane}

Pozzo 1700 - Andrea Pozzo, Perspectiva pictorum et architectorum Andreae Putei e Societate Jesu. Pars secunda, Roma 1700.

\section{Opracowania}

BANIA 2018 - Zbigniew Bania, Owalne tempietta w małej architekturze sakralnej w Polsce, „TECHNE. Seria nowa” 2018, nr 1, s. 133-146.

BARCZYK 2019 - Alina Barczyk, Pałac ,jakoż nigdzie w Polsce nie masz”. Saskie inspiracje w architekturze warszawskiej rezydencji marszałka wielkiego koronnego Józefa Wandalina Mniszcha, „Biuletyn Historii Sztuki”, t. 81 (2019), nr 3, s. 415-440.

BARTCZAKOWA 1970 - Aldona Bartczakowa, Jakub Fontana: architekt warszawski XVIII wieku, Warszawa 1970.

BARUCH 1914 - Maksymilian Baruch, Baryczkowie. Dzieje rodu patrycyuszowskiego Starej Warszawy, Warszawa 1914.

Bernatowicz 1999 - Aleksandra Bernatowicz, Contesse (Contes, Kontes, Kontessa, Kontesz), [w:] Saur Allgemeines Künstlerlexikon. Die Bildenden Künstler aller Zeiten und Völker. Bd. 21, red. Günter Meißner, München-Leipzig 1999, s. 3.

BernAtowicz 2003 - Aleksandra Bernatowicz, Plersch Jan Bogumit, [w:] Słownik artystów polskich i obcych w Polsce działajacych (zmarlych przed 1966 r.). Malarze, rzeźbiarze, graficy, t. 7, red. Urszula Makowska, Warszawa 2003, s. 266-276.

Bernatowicz 2016 - Tadeusz Bernatowicz, Kościót wizytek w Warszawie a Benedykt de Renard i architektura późnobarokowego eklektyzmu rzymskiego przełomu XVII i XVIII wieku, [w:] Sztuka Polski Środkowej. Studia VI, red. Alina Barczyk, Piotr Gryglewski, Łódź 2016, s. 31-77.

CHudobA 1959 - Tadeusz Chudoba, Z zagadnień handlu wiślanego Warszawy w XVI wieku, „Przegląd Historyczny”, t. 50 (1959), nr 2, s. 297-321.

CzYż 2010 - Anna Sylwia Czyż, Łowicz. Kolegiata Wniebowzięcia NMP, Warszawa 2010.

DACKA-GórzYŃSKA 2011 - Iwona M. Dacka-Górzyńska, O nieznanych dzieciach magnaterii polskiej w świetle parafialnych metryk zmarlych kościoła św. Krzyża w Warszawie z lat 1670-1801: wybrane przykłady, „Przegląd Historyczny”, t. 102 (2011), nr 3, s. 459-482.

DobrzenieCKi 1948 - Tadeusz Dobrzeniecki, Późnogotycki krucyfiks warszawski, „Biuletyn Historii Sztuki i Kultury", R. 10 (1948), nr 3/4, s. 231-244.

FRYCZ 1975 - Jerzy Frycz, Restauracja i konserwacja zabytków architektury $w$ Polsce $w$ latach 1795-1918, Warszawa 1975.

FUKIER 1973 - Henryk Maria Fukier, Wspomnienia staromiejskie, Warszawa 1973.

GAJEWSKI 1986 - Jacek Gajewski, Sztuka w prymasowskim Łowiczu, [w:] Łowicz: dzieje miasta, Warszawa 1986, s. 462-606. 
GAJEWSKI 2012 - Jacek Gajewski, Nagrobek Jana Tarly w Warszawie i zagadnienie jego rekonstrukcji (mała architektura w twórczości Jakuba Fontany; Plersch i warsztat), „Arteria. Rocznik Wydziału Sztuki Politechniki Radomskiej” 2012, nr 10, s. 58-91.

GRACZYK/MARSZTALSKA 2014 - Waldemar Graczyk, Jolanta M. Marsztalska, Klasztor karmelitów bosych w Czernej od pierwszej połowy XVII do końca XIX wieku. Dzieje-gospodarka-kulturaludzie, Kraków 2014.

IDZIK 2020 - Grzegorz Idzik, Skarb ocalony z gruzów, „Spotkania z Zabytkami” 2020, nr 3-4, s. $24-31$.

JAROSZEWSKi 1992 - Tadeusz Stefan Jaroszewski, Pałace i dwory w okolicach Warszawy, Warszawa 1992.

Jurkowlaniec 2008 - Grażyna Jurkowlaniec, Epoka nowożytna wobec średniowiecza: Pamiątki przeszłości, cudowne wizerunki, dzieła sztuki, Wrocław 2008.

Kaplica 1867 - Kaplica Pana Jezusa w Warszawie, „Opiekun Domowy” 1867, nr 16, s. 1-2 (121-122).

KARPOWICZ 1986 - Mariusz Karpowicz, Piękne nieznajome. Warszawskie zabytki XVII i XVIII wieku, Warszawa 1986.

KowAlCzyk 1994 - Jerzy Kowalczyk, Rola Rzymu w późnobarokowej architekturze polskiej, „Rocznik Historii Sztuki”, t. 20 (1994), s. 215-308.

KRÓLIK 1990 - Ludwik Królik, Kapituła kolegiacka w Warszawie do końca XVIII wieku, Warszawa 1990.

KUROWSKI 1841 - Franciszek Ksawery Kurowski, Wiadomość historyczna o kościele metropolitalnym warszawskim pod tytułem Ś. Jana, Warszawa 1841.

KwiATKOWSKA 1978 - Maria I. Kwiatkowska, Katedra św. Jana, Warszawa 1978.

KwiATKOwsKi 1939 - Władysław Kwiatkowski, Prymasowska kapituła i kolegiata w Łowiczu, Warszawa 1939.

KwiATKOwSKi 1983 - Marek Kwiatkowski, Stanisław August: Król-Architekt, Wrocław-Warszawa-Kraków-Gdańsk-Łódź 1983.

KZSP 1954 - Katalog Zabytków Sztuki w Polsce, t. 2: Województwo Łódzkie, z. 5: Powiat Łowicki, red. Jerzy Z. Łoziński, Warszawa 1954.

LibROWsKi 1977 - Stanisław Librowski, Sumariusz wpisów kopiariusza kapituły kolegiackiej w Łowiczu z przełomu XVIII i XIX wieku (z kontynuacja do roku 1961), „Archiwa, Biblioteki i Muzea Kościelne”, t. 34 (1977), s. 191-290.

LiLEY KO 1989 - Jerzy Lileyko, Najcenniejsze zabytki Warszawy, Warszawa 1989.

LORENTZ 1966 - Stanisław Lorentz, Wczesne prace Szregera w kolegiacie łowickiej, [w:] Sztuka i historia. Księga pamiątkowa ku czci profesora Michała Walickiego, red. Jan Białostocki, Warszawa 1966, s. 177-190.

Lorentz 1981 - Stanisław Lorentz, Placidi $w$ Łowiczu, „Biuletyn Historii Sztuki”, t. 43 (1981), nr 1, s. 32-33.

ŁUGOWSKI 2016 - Piotr Ługowski, Jakub Fontana i Domenico Merlini a rokokowa faza budowy kościoła kamedułów na Bielanach w Warszawie, [w:] Kameduli w Warszawie, 1641-2016. 375 lat fundacji eremu na Bielanach, red. Anna Sylwia Czyż, Karol Guttmejer, Warszawa 2016, s. 137-151.

MichalıK 1996 - Bożenna Michalik, Nauczanie początkowe w Warszawie stanisławowskiej, „Rocznik Warszawski”, t. 26 (1996), s. 5-26.

MikockA-Rachubowa 2007 - Katarzyna Mikocka-Rachubowa, Redler Johann Chrysostomus, [w:] Słownik artystów polskich i obcych w Polsce działających (zmarlych przed 1966 r.). Malarze, rzeźbiarze, graficy, t. 8, red. Irena Bal, Urszula Makowska, Katarzyna Mikocka-Rachubowa, Warszawa 2007, s. 265-272.

Mossakowski 2012 - Stanisław Mossakowski, Tylman z Gameren (1632-1706). Twórczość architektoniczna w Polsce, Warszawa-Monachium-Berlin 2012. 
Mrozowski 2003 - Przemysław Mrozowski, Poczet Arcybiskupów Gnieźnieńskich Prymasów Polski, Warszawa 2003.

Nieborów 1970 - Nieborów 1945-1970. Księga pamiątkowa, red. Urszula Popłonyk, Warszawa 1970.

NiECIECKI 1997 - Jan Nieciecki, Monument serc Stefana Mikołaja i Katarzyny Aleksandry Branickich w Białymstoku, „Biuletyn Konserwatorski Województwa Białostockiego, t. 3 (1997), s. 5-18.

OCZY KOwsKi 2020 - Romuald Oczykowski, Przechadzka po Łowiczu, Łowicz 2020.

Olé́sKa 2011 - Oleńska Anna, Jan Klemens Branicki. Sarmata nowoczesny. Kreowanie wizerunku poprzez sztuke, Warszawa 2011.

Osiecka-Samsonowicz 2016 - Hanna Osiecka-Samsonowicz, Kleinpold Erhard, [w:] Słownik architektów i budowniczych środowiska warszawskiego XV-XVIII wieku, red. Paweł Migasiewicz, Hanna Osiecka-Samsonowicz, Jakub Sito, Warszawa 2016, s. 37-45.

Pabiś-Gagis/Woziński 2009 - Jolanta Pabiś-Gagis, Andrzej Woziński, Późnogotycki krucyfiks w kościele św. Trójcy w Gdańsku. Konserwacja, forma, styl, pochodzenie, „Porta Aurea”, t. 7-8 (2009), s. 13-44.

Prokop 2006 - Krzysztof R. Prokop, Sakry ordynariuszy i sufraganów poznańskich w XVIII stuleciu, „Ecclesia. Studia z Dziejów Wielkopolski”, t. 2 (2006), s. 119-150.

SCHlETz 2011 - Alfons Schletz, Ks. biskup Michał Bartłomiej Tarło, opiekun ubogich, „Nasza Przeszłość", t. 115/116 (2011), s. 23-32 [przedruk artykułu z 1946 roku].

SierockA-PoŚPIECH 2015 - Maria Sierocka-Pośpiech, Celebransi chrztów i ślubów w parafi św. Jana Chrzciciela $w$ Warszawie w latach 1583-1700 (na podstawie ksiag metrykalnych), „Miscellanea Historico-Archivistica" 2015, nr 22, s. 157-168.

Siтo 2009 - Jakub Sito, Firmitas, Venustas i Magnificentia. O użyciu kamienia w warszawskiej architekturze i rzeźbie doby saskiej, [w:] Materiał rzeźby. Między techniką a semantyką / Material of Sculpture. Between Technique and Semantics, red. Aleksandra Lipińska, Wrocław 2009, s. 403-421.

SiTO 2010a - Jakub Sito, Nagrobek kardynała Michała Stefana Radziejowskiego (1645-1722) z około 1719-1722 r., [w:] Serce miasta. Kościół Świętego Krzyża w Warszawie, red. Kazimierz Starbałło, Michał Wardzyński, Warszawa 2010, s. 222-225.

SITO 2010b - Jakub Sito, Warszawskie inicjatywy budowlano-artystyczne Augusta Aleksandra Czartoryskiego $w$ świetle materiałów archiwalnych $z$ Biblioteki Czartoryskich $w$ Krakowie, Warszawa 2010.

SiTO 2012 - Jakub Sito, Franz Anton Vogt, rzeźbiarz warszawskiego rokoka, [w:] Splendor i fantazja. Studia nad rzeźba rokokowa w dawnej Rzeczypospolitej i na Śląsku, red. Paweł Migasiewicz, Warszawa 2012, s. 71-108.

SiTO 2013 - Jakub Sito, Wielkie warsztaty rzeźbiarskie Warszawy doby saskiej. Modele kariery, formacja artystyczna, organizacja produkcji, Warszawa 2013.

SiTo 2016 - Jakub Sito, Bay Carlo Antonio Maria, [w:] Słownik architektów i budowniczych środowiska warszawskiego XV-XVIII wieku, red. Paweł Migasiewicz, Hanna Osiecka-Samsonowicz, Jakub Sito, Warszawa 2016, s. 37-45.

SKRABSKI 2016 - Józef Skrabski, The stonemasonry centre in Dębnik under the management of the discalced Carmelites in Czerna, „Folia Historica Cracoviensia”, t. 22 (2016), s. 419-436.

SobIEsZCZAŃSKi 1967 - Franciszek M. Sobieszczański, Kościół św. Jana, [w:] idem, Warszawa. Wybór publikacji, t. 2, Warszawa 1967.

STEFAŃSKi 2005 - Krzysztof Stefański, Architektura XIX wieku na ziemiach polskich, Warszawa 2005.

SwĘDROWSKI 2012 - Jerzy Swędrowski, Arcybiskupi gnieźnieńscy a kultura: wybrane zagadnienia, „Studia Prymasowskie”, t. 6 (2012), s. 343-357.

SZYBKOWSKI 2017 - Sobiesław Szybkowski, Korespondencja książąt mazowieckich z rada miasta Gdańska w latach 1466-1526, [w:] Dziedzictwo książąt mazowieckich. Stan badań i postulaty 
badawcze, red. Janusz Grabowski, Rafał Mroczek, Przemysław Mrozowski, Warszawa 2017, (Zamek Królewski w Warszawie. Studia i materiały, t. 7), s. 283-303.

SzYPOwSCY 1999 - Maria Szypowska, Andrzej Szypowski, Gdy wchodzisz w progi katedry..., Warszawa 1999.

TAtarkiewiCz 1955 - Władysław Tatarkiewicz, Dominik Merlini, Warszawa 1955.

WANAT 1992 - Benignus J. Wanat, Maryjne sanktuarium karmelitów bosych w Czernej, Kraków 1992.

WARDZYŃSKI 2015a - Michał Wardzyński, Marmur i alabaster $w$ rzeźbie i małej architekturze Rzeczypospolitej. Studium historyczno-materiałoznawcze przemian tradycji artystycznych od XVI do początku XVIII wieku, Warszawa 2015.

WARDZYŃSKI 2015b - Michał Wardzyński, Sztuka nowożytna na Mazowszu. Zarys problematyki, [w:] Dzieje Mazowsza, t. 2: Lata 1527-1794, red. Jan Tyszkiewicz, Warszawa 2015, s. 629-731.

WARDZYŃSKI 2018 - Michał Wardzyński, Szpital św. Rocha przy Krakowskim Przedmieściu i jego architektoniczne przemiany w XVIII-XX wieku, „Almanach Warszawy”, t. 12 (2018), s. 137-163.

WARDZYŃski/JAmski/KowAlski 2013 - Michał Wardzyński, Piotr Jamski, Hubert Kowalski, Lapidarium warszawskie. Szlachetne materiały kamieniarskie w XVI i XVII wieku, Warszawa 2013.

Warszawa 1980 - Warszawa, jej dzieje i kultura, red. Aleksander Gieysztor, Janusz Durko, Warszawa 1980.

Wątroba 2016 - Przemysław Wątroba, Merlini Domenico, [w:] Słownik architektów i budowniczych środowiska warszawskiego XV-XVIII wieku, red. Paweł Migasiewicz, Hanna OsieckaSamsonowicz, Jakub Sito, Warszawa 2016, s. 314-319.

WĄTrobA 2019 - Przemysław Wątroba, Rysunki architektoniczne i dekoracyjne. Tylman z Gameren, t. 1, Warszawa 2019.

Wieteska 1985 - Józef Wieteska, Prymas Adam Komorowski. Fundacje w Łowiczu i pogrzeb: tytuł Księstwa Łowickiego, Warszawa 1985.

ZAHORSKi 2017 - Andrzej Zahorski, Warszawa średniowieczna, [w:] Historia Warszawy, red. Marian M. Drozdowski, Andrzej Sołtan, Andrzej Zahorski, Warszawa 2017, s. 9-36.

ZDZIARSKA 1988 - Romana Zdziarska, Kościół i klasztor misjonarzy w Siemiatyczach w pierwszej połowie XVIII w., „Kwartalnik Architektury i Urbanistyki”, t. 26 (1988), nr 1, s. 103-122. 


\section{Warsaw and Łowicz Two collegiate chapels of Christ Crucified in the eighteenth century}

$\ln$

the collegiate churches in Warsaw and Łowicz (two particularly important residential cities of the Republic of Poland in the modern era), in the $18^{\text {th }}$ century, chapels were erected for the exhibition of late Gothic crucifixes, famous for their graces. The chapels were distinguished by remarkable architectural forms and innovative artistic programs. Both were built on the extensions of the northern aisles and were under the care of chapters, although their creation was financed from funds provided by powerful patrons. In the case of Łowicz, the construction was the fulfillment of the volition expressed in the will of Primate Adam Ignacy Komorowski, who assigned this part of the temple for his mausoleum. In Warsaw, the the right to patronage was passed on to successive families - the patronage was granted to the Szembek and Branicki families, among others. The features connecting both investments were also: the connections of both collegiate chapters and the special status of said churches, associated with the most important people in the Republic of Poland - the king (and, in a broader sense, the Seym and court circles) and the primate, i.e. the interrex. Although the chapels' architecture was developed almost half a century apart, one can see the mutual dependence of the forms used. The interiors boast even more analogies because the Warsaw chapel, built in the second decade of the $18^{\text {th }}$ century, was transformed at the initiative of Jan Klemens Branicki in the early 1860s - while the mausoleum in Łowicz was being built. Probably both buildings employed the workshop of the Warsaw architect Jakub Fontana. In both chapels, influences of palace architecture are visible, manifested in the lightness of forms, rococo style and colors based on combining white with gold. The connection to residential interiors was enhanced especially by crimson wall coverings introduced by Fontana in the present St. John cathedral. The presented analysis, based on archival queries and in situ observations, made it possible to clarify the findings so far, as well as to show the construction process and transformations of the discussed objects. A look at their architectural form and decor details made it possible to identify sources of inspiration, probable contractors and to confirm the relationship between two particularly important examples of $18^{\text {th }}$-century collegiate chapels.

Keywords: $18^{\text {th }}$ century, Branicki Jan Klemens, Lowicz, Warsaw, early modern sacral architecture, patronage of bishops, baroque art, miraculous images (crucifixes), mausoleums, sepulchral art 